\title{
CARBON COLONIALISM OR CLIMATE JUSTICE? INTERROGATING THE INTERNATIONAL CLIMATE REGIME FROM A TWAIL PERSPECTIVE
}

\section{Julia Dehm*}

This article provides a TWAIL critique of the United Nations Framework Convention on Climate Change [UNFCCC] in the aftermath of the 21st Conference of the Parties in Paris in December 2015. It engages with criticisms from the social and climate justice movement that the UNFCCC is promoting forms of "carbon colonialism" or "CO $\mathrm{O}_{2}$ lonialism" through its support for and establishment of international carbon trading and offsetting strategies. It proposes that using a jurisdictional approach to examine how the authority of the UNFCCC is authorized can provide key analytical tools to understand the regime. The article examines the way in which the regime is authorized by an invocation of "common concern" even as it promotes policies that marginalize the interests of those already most vulnerable to climate change. It concludes by suggesting that climate justice movements already are building different forms of commonality and that these alternative commonalties represent important new ways of thinking about global action on climate change.

L'auteure de cet article fait une critique, à travers le prisme de TWAIL, de la Convention-cadre des Nations Unies sur les changements climatiques [CCNUCC] au lendemain de la $21^{e}$ Conférence des Parties, tenue à Paris en décembre 2015. Elle ajoute aux reproches formulés par le mouvement de justice sociale et climatique, selon lequel la CCNUCC fait la promotion de formes de "colonialisme du carbone" ou de " $\mathrm{CO}_{2}$ lonialisme » en appuyant et en établissant des stratégies internationales d'échanges de droits d'émission de carbone et de compensation carbone. L'auteure soutient qu'en étudiant selon une démarche juridictionnelle la façon dont le pouvoir de la CCNUCC est approuvé, on se donne d'importants moyens analytiques pour comprendre ce régime. L'auteure se penche sur la manière dont ce régime est approuvé par l'invocation d'une "préoccupation commune » même lorsque cela favorise des politiques qui marginalisent les intérêts de populations déjà très fragiles vis-à-vis des changements climatiques. Elle conclut en laissant entendre que les mouvements en faveur de la justice climatique s'emploient déjà à définir différents éléments communs et que ceux-ci constituent de nouvelles manières de réfléchir sur les mesures mondiales en matière de changements climatiques.

Julia Dehm is a Postdoctoral Fellow at the Rapoport Center for Human Rights and Justice, University of Texas at Austin, jdehm@law.utexas.edu. Many thanks to the people who participated in the TWAIL Conference in Cairo in February 2015 and the subsequent workshop at the University of Windsor in June 2015 where an earlier draft of this article was presented and discussed. Many thanks also to the editors of this special edition, especially Usha Natarajan for helpful guidance in clarifying the argument, as well as to the two anonymous referees. Finally, many thanks are also due to Adil Hasan Khan for his comments on earlier versions of this article. 


\section{INTRODUCTION}

At this critical moment for international climate regulation, the divergent assessments of the progress made in international negotiations could not be starker. In December 2015, the first universal legallybinding climate agreement, the "Paris Agreement", was reached at the $21^{\text {st }}$ Conference of the Parties [COP] to the United Nations Framework Convention on Climate Change [UNFCCC]. ${ }^{1}$ This Agreement has both been heralded as a "historic agreement to combat climate change and unleash action and investment towards a low carbon, resilient and sustainable future", 2 more pragmatically evaluated as "the best that could be achieved at this place and time", 3 but also condemned by climate scientist James Hanson as a "fraud", "fake" and "bullshit". ${ }^{4}$ Climate justice groups have also been highly critical of the agreement, arguing that it "undermines the rights of the world's most vulnerable communities and has almost nothing binding to ensure a safe a livable future for future generations". 5 The existence of such highly divergent perspectives on climate negotiations is not new. At the conclusion of the Lima COP in December 2014, the press release by the Secretariat of the UNFCCC declared the world is "on track to a new universal climate agreement", with negotiations reaching a "new level of realism and understanding about what needs to be done now". ${ }^{6}$ In stark contrast, civil society groups made scathing assessments that the outcomes of the Lima meeting ${ }^{7}$ failed people and planet, ${ }^{8}$ were a "travesty for climate justice", 9 and that the negotiations represented "an exercise in futility and delay". ${ }^{10}$ More broadly, for over a decade, grassroots movements for climate justice have been questioning not simply the adequacy of

1 Paris Agreement (opened for signature 22 April 2016 and entered into force 4 November 2016) [Paris Agreement], see also, UNFCCC Decision 1/CP.21 “Adoption of the Paris Agreement”, FCCC/CP/2015/10/Add.1 (29 January 2016).

2 See United Nations Framework Convention on Climate Change, "Historic Paris Agreement on Climate Change: 195 Nations Set Path to Keep Temperature Rise Well Below 2 Degrees Celsius", UN Climate Change Newsroom, (12 December 2015), online: <http://newsroom.unfccc.int/unfccc-newsroom/finale-cop21/>.

3 See Annalisa Savaresi, "The Paris Agreement: A Rejoinder", EJIL: Talk! (16 February 2016), online: $<$ http://www.ejiltalk.org/the-paris-agreement-a-rejoinder/>.

4 Oliver Milman, "James Hanson, father of climate change awareness, calls Paris talks 'a fraud", The Guardian, (12 December 2015), online: <http://www.theguardian.com/environment/2015/dec/12/james-hansen-climate-change-paristalks-fraud $>$.

5 Global Justice Now, "Final COP21 text a disaster for the world's most vulnerable and future generations" (12 December 2015), online: <http:/www.globaljustice.org.uk/news/2015/dec/12/final-cop-21-text-disaster-worlds-most-vulnerableand-future-generations $>$. For an assessment of the Paris Agreement see also Julia Dehm, "Reflections on Climate Action in the Aftermath of Paris", Human Rights in Ireland (12 January 2016), online: $<$ http://humanrights.ie/economicrights/reflections-on-climate-action-in-the-aftermath-of-paris/>.

6 United Nations Framework Convention on Climate Change Press Release, "Lima Call for Climate Action puts the world on track to Paris 2015", (UNFCCC, 14 December 2014), online: <http://newsroom.unfccc.int/lima/lima-call-for-climateaction-puts-world-on-track-to-paris-2015/>.

7 "Lima Call for Climate Action", UNFCCC, Decision 1/CP.20, FCCC/CP/2014/10/Add.1 (2 February 2015).

8 See the statement by climate justice groups including Jubilee South and Friends of the Earth International: Climate and Capitalism, "Lima Agreement Fails Humanity and the Earth" (14 December 2014), online: $<$ http://climateandcapitalism.com/2014/12/14/lima-agreement-fails-humanity-earth/>.

9 John Vidal, “Is the Lima Deal a Travesty of Global Climate Justice?", The Guardian (15 December 2014), online: $<$ http://www.theguardian.com/global-development/2014/dec/15/lima-deal-global-climate-justice>.

10 Oscar Reyes, “At the Lima Climate Talks, it was groundhog day all over again”, Foreign Policy in Focus (18 December 2014), online: <http://fpif.org/lima-climate-talks-groundhog-day/>. 
action taken under the umbrella of the UNFCCC but also the kind of action being taken: its rationality, its underlying neo-liberal market-driven ethos, and the ensuing distributional consequences. From a climate justice standpoint, pertinent critiques have been made of the role played by the UNFCCC in promoting "false solutions" such as carbon trading and carbon offset schemes that more deeply perpetuate the inequalities at the heart of the climate crisis. Social movements have criticized these schemes as an ineffectual response that abrogates the responsibility of key polluters whilst threatening the livelihoods of those communities with limited responsibility for and high vulnerability to climate change. For these reasons some have described the UNFCCC framework as promoting a form of "carbon colonialism" or " $\mathrm{CO}_{2}$ lonialism". These are critiques that TWAIL, postcolonial and critical legal scholars should take seriously. This article thereby interrogates the underlying dynamics of the UNFCCC regime and analyzes how this regime directed toward addressing a "common concern", namely anthropocentric climate change, is also having the effect of authorizing new forms of global authority over parts of the Global South.

Part II explains civil society critiques of the UNFCCC regime, their concerns about climate justice, and the origins of the terms carbon colonialism and $\mathrm{CO}_{2}$ lonialism. In light of these concerns, Part III critically assesses third world approaches to climate justice issues, considering TWAIL scholarship on climate change as well the approaches of Third World states as articulated through the general principle of common but differentiated responsibilities for the global environment. In light of some of the shortcomings of existing approaches, Part IV proposes a jurisdictional approach, shifting focus to understanding the climate regime's mode of authorization and how this has been actualized in practice. Paying attention to how an authorization in the name of a "common concern" is taken up, how it is organized, and therefore also its effects and its exclusions, opens us up to thinking about the multitude of ways in which a "common concern" can be ordered and which of these orderings may open and which may foreclose possibilities for climate justice. Part V considers different ways in which a "common concern" about anthropocentric climate change could be patterned, organized and actualized. It suggests that alternative approaches to confronting the urgent task of climate mitigation are not only envisioned but are being materialized, often through the bodies being put directly on the line to prevent logging activities, coal-fired power stations or the expansion of fossil fuel extraction. ${ }^{12}$ I read into these actions forms of jurisdictional practices seeking to bring into being different modes of organizing a "common concern" and thereby of authorizing lawful relations.

\section{THE PARIS AGREEMENT AND THE UNFCCC}

The international community reached the Paris Agreement in December 2015 at COP21. The Agreement has as its objective to "strengthen the global response to the threat of climate change, in the

1 See UNFCCC, 1771 UNTS 107 (opened for signature 9 June 1992, entered into force 21 March 1994), Preamble.

12 See for example Christine Hauser, "Greenpeace Activists Dangle from Oregon Bridge for 2nd Day to Protect Arctic Drilling”, New York Times (30 July 2015), online: <http://www.nytimes.com/2015/07/31/us/greenpeace-activistsdangle-from-oregon-bridge-for-2nd-day-to-protest-arctic-drilling.html?_r=1> and Jemima Garrett, "Pacific Climate Warriors in Australia to protest coal industry", ABC Online (Australia) (14 October 2014), online:

$<$ http://www.abc.net.au/news/2014-10-13/pacific-climate-warriors-to-protest-newcastle-coal-port/5809392>. 
context of sustainable development and efforts to eradicate poverty" including by "holding the increase in global average well below $2^{\circ} \mathrm{C}$ above pre-industrial levels and pursuing efforts to limit the temperature increase to $1.5^{\circ} \mathrm{C}$ above pre-industrial levels" ${ }^{13}$ In order to achieve these objectives each country was asked to communicate its own "nationally determined contributions" [NDCs]. ${ }^{14}$ However, various analysis have found that the $160 \mathrm{NDCs}$ that cover 187 countries (the European Union made a joint submission), ${ }^{15}$ if properly implemented would put the world on track for at least $2.7^{\circ} \mathrm{C}$ warming above pre-industrial levels. ${ }^{16}$ Implementation of the commitments made in the NDCs would still see an expected rise in greenhouse gas emissions of 8-18 percent by 2025 and 11-22 percent in 2030 from 2010 levels. $^{17}$

Below I briefly discuss some of the sections of the agreement relevant to mitigation. ${ }^{18}$ Articles 5 and 6 of the Paris Agreement make reference to expanded carbon trading mechanisms. Further, over half the NDCs state they intend to use or will consider using carbon-trading mechanisms, ${ }^{19}$ suggesting that carbon trading will continue to be utilized as key tool for achieving climate mitigation. ${ }^{20}$ The Agreement recognizes that "some Parties choose to pursue voluntary cooperation in the implementation of their nationally determined contributions" and that such "cooperative approaches" may involve the "use of internationally transferred mitigation outcomes". 21 Although the words "carbon markets" or "carbon trading" are not explicitly mentioned, these provisions provide for the establishment of such mechanisms as part of the Paris Agreement, ${ }^{22}$ whose rules, modalities and procedures are to be adopted at a subsequent meeting. ${ }^{23}$ Article 5 of the Paris Agreement states that Parties "should take action to conserve and enhance, as appropriate, sinks and reservoirs of greenhouse gases...including forests". ${ }^{24}$ More specifically, the Agreement encourages Parties to "implement and support" the Reducing

13 Paris Agreement, supra note 1, Article 2(1)(a).

14 Ibid, Article 4(2).

15 "INDCs as communicated by Parties" online: <http://www4.unfccc.int/submissions/indc/Submission\%20-

Pages/submissions.aspx>.

16 "Climate pledges will bring $2.7^{\circ} \mathrm{C}$ of warming, potential for more action" Climate Action Tracker, 8 December 2015 , online: $<$ http://climateactiontracker.org/news/253/Climate-pledges-will-bring-2.7C-of-warming-potential-for-moreaction.html >; see also "Synthesis report on the aggregate effects of the intended nationally determined contributions: Note by the Secretariat" FCCC/CP/2015/7 (30 October 2015) which found that "[t]he estimated aggregate annual global emission levels resulting from the implementation of the INDCs do not fall within least-cost $2^{\circ} \mathrm{C}$ scenarios by 2025 and 2030 " at para 39.

17 Ibid at para 34.

18 The Paris Agreement also has provisions on adaptation (Article 7), loss and damage (Article 8), climate finance (Article 9), technology development and transfer (Article 10), capacity-building (Article 11), transparency of action (Article 13), periodic review (Article 14), compliance (Article 15) and others. However, the focus of this article is on mitigation. Gareth Bryant, "Paris vs. Climate Change, or Paris vs. the Climate?", Progress in Political Economy (3 December 2015), online: $<$ http://ppesydney.net/paris-vs-climate-change-or-paris-vs-the-climate/>.

20 See Steffen Böhm, "How emissions trading at Paris climate talks has set us up for failure", The Conversation (14 December 2015), online: $<$ https://theconversation.com/how-emissions-trading-at-paris-climate-talks-has-set-us-up-forfailure-52319>.

21 Paris Agreement, supra note 1, Article 6(1) and (2)

22 Ibid at Article 6(4).

23 Ibid at Article 6(7).

24 Ibid at Article 5(1). 
Emissions from Deforestation and Forest Degradation [REDD+] framework established under the Convention. ${ }^{25}$ The REDD + framework, established by a series of decisions at the Warsaw COP in $2013,{ }^{26}$ seeks to provide economic incentives to address tropical deforestation and forest degradation in the global South by allowing credits to be produced from such "result-based" actions. ${ }^{27}$

These carbon-trading mechanisms included in the Paris Agreement represent an expansion of the "flexibility mechanisms" provided for in the Kyoto Protocol. ${ }^{28}$ The Kyoto Protocol provides for three different types of "flexibility mechanisms". Article 17 of the Protocol authorizes Annex B parties to "participate in emissions trading for the purposes of fulfilling their commitments", provided that such trading is "supplemental" to domestic action. ${ }^{29}$ Kyoto does not simply allow for the trading of allowances but provides for the production of allowances or credits from activities considered to represent "saved" or "prevented" emissions. These two mechanisms are "Joint Implementation", authorized by Article 6, ${ }^{30}$ and the "Clean Development Mechanism" [CDM] authorized by Article $12 .{ }^{31}$ The former allows an Annex I party to "transfer to, or acquire from" emission reduction units that result from "projects aimed at reducing anthropogenic emissions by sources" or "enhancing anthropocentric removals by sinks of greenhouse gases" located in another Annex I country, provided that such projects have the approval of all parties involved and they provide a "reduction in emissions by sources, or an enhancement of removals by sinks, that is additional to any that would otherwise occur" ${ }^{32}$ Similarly, Article 12 authorizes the creation of carbon offset credits from projects located in non-Annex I countries provided the emission reductions resulting from each project represent "real, measurable and long-term benefits related to the mitigation of climate change" ${ }^{33}$ and that such reductions are "additional to any that would occur in the absence of the certified project activity." "The objectives of the CDM are to deliver globally-aggregate and symbiotic benefits; to assist in "achieving sustainable development" in

25 Ibid at Article 5(2).

26 These are: Decision 9/CP.19 "Work programme on results-based finance to progress the full implementation of the activities referred to in decision 1/CP.16, paragraph 70"; Decision 10/CP.19 "Coordination of support for the implementation of activities in relation to mitigation actions in the forest sector by developing countries, including institutional arrangements"; Decision 11/CP.19 "Modalities for national forest monitoring systems"; Decision 12/CP.19 "The timing and the frequency of presentations of the summary of information on how all the safeguards referred to in decision 1/CP.16, appendix I, are being addressed and respected"; Decision 13/CP.19 "Guidelines and procedures for the technical assessment of submissions from Parties on proposed forest reference emission levels and/or forest reference levels"; Decision 14/CP.19 "odalities for measuring, reporting and verifying"; and Decision 15/CP.19 "ddressing the drivers of deforestation and forest degradation".

27 On REDD+ see Maria Eugenia Recio, "The Warsaw Framework and the Future of REDD+" (2014) 24:1 YB Intl Env L 37, see also Julia Dehm, Reconsidering REDD+: Law, life, limits and growth in crisis (PhD Thesis, Melbourne Law School, 2015) [unpublished].

28 Kyoto Protocol to the United Nations Framework Convention on Climate Change, UN Doc FCCC/CP/1997/7/Add.1 (opened for signature 11 December 1997, entered into force 16 February 2005) [Kyoto Protocol].

29 Ibid at Article 17.

30 Joint Implementation is accounted for in Article 3(10) and 3(11).

31 The CDM is accounted for in Article 3(12).

32 Kyoto Protocol supra note 28 at Article 6(1)(b).

33 Ibid at Article 12(5)(b).

34 Ibid at Article 12(5)(c). 
non-Annex I countries, by facilitating the transfer of technology and finance, ${ }^{35}$ whilst also assisting Annex I parties achieve compliance in the most cost-effective manner by allowed "certified emission reductions accruing from such projects to contribute to compliance". ${ }^{36}$ The voluntary participation ${ }^{37}$ of both "producing" and "purchasing" countries should "contribut(e) to the ultimate objective of the Convention." 38 The CDM depends upon complex regulatory infrastructure, including a supervisory Executive Board ${ }^{39}$ as well as validation and verification by private "Operational Entities". 40

\section{CIVIL SOCIETY CRITIQUES OF THE UNFCCC: CLIMATE JUSTICE, CARBON COLONIALISM AND CO $\mathrm{CO}_{2}$ LONIALISM}

Civil society movements have been critical not just of the lack of effective climate action from the UNFCCC but also the form of climate action it is promoting. In particular, social movements have highlighted environmental and social justice problems arising from the utilization of carbon markets as a key international climate mitigation strategy, enabled through the Kyoto Protocol's "flexibility mechanisms". ${ }^{41}$ Academics and activists have demonstrated that claims that the CDM will facilitate lowest-cost climate mitigation and provide climate finance to countries in the South are dubious given that the "additionality" of many of these "offset" projects is questionable. ${ }^{42}$ That is, many of these claimed reductions do not represent "real emission" reductions. Moreover, given these offsets can be purchased and used to legitimate further greenhouse gas emissions in the North, environmental groups allege that such carbon trading provides a "dangerous distraction" that prevents urgently necessary changes in energy production and distribution. ${ }^{43}$ Activist academics have documented some of the negative social impacts such projects have had in communities where they have been located. ${ }^{44}$ For Indigenous peoples the support of "carbon sinks" through afforestation and reforestation projects under the $\mathrm{CDM}^{45}$ and more recently a proposed REDD+ scheme have been particularly contentious, ${ }^{46}$ as such projects have been viewed as a form of "green grabbing" or the appropriation of land in the South for

35 Ibid at Article 12(2) and (3)(a).

36 Kyoto Protocol supra note 28 at Article 12(2) and (3)(b).

37 Ibid at Article 12(5)(a).

38 Ibid at Article 12(2).

39 Ibid at Article 12(4).

40 Ibid at Article 15(5).

41 These are carbon trading (Article 17), joint implementation (Article 6) and the Clean Development mechanisms (Article 12).

42 On "additionality of these projects", see Lambert Schneider, "Assessing the additionality of CDM projects: practical experiences and lessons learned" (2009) 9 Climate Policy 242.

43 Simon Bullock, Mike Childs \& Tom Picken, "A Dangerous Distraction: Why Offsetting is Failing the Climate and People: The Evidence" (London: Friends of the Earth England, Wales and Northern Ireland, 2009).

44 See for example, Steffen Böhm \& Siddhartha Dabhi, eds, Upsetting the Offset: The Political Economy of Carbon Markets (London: MayFlyBooks, 2009).

45 For case study discussions of CDM afforestation and reforestation projects, see Larry Lohmann, Carbon Trading: $A$ Critical Conversation on Climate Change, Privatization and Power (Uppsala:The Dag Hammarskjöld Centre, 2006) [Lohmann, Carbon Trading].

46 On REDD+, see Tom Griffiths "Seeing REDD? Forests, climate change mitigation and the rights of indigenous peoples" (updated version, Forest Peoples' Programme, 2009). 
ostensible environmental ends. ${ }^{47}$ It has been alleged that establishment of large-scale tree plantations as "carbon sinks" in the South "would result in land being used at the expense of local people, accelerate deforestation, deplete water resources and increase poverty". ${ }^{48}$

After reviewing the literature on international carbon markets, Rebecca Pearse and Steffen Böhm present five arguments that demonstrate the flawed practices of carbon markets and five arguments that carbon trading cannot be reformed. ${ }^{49}$ They highlight the empirical history of their failure, the ways carbon markets have promoted unjust development and "green grabbing", how carbon markets have provided loopholes for polluters, operated as fossil fuel subsidies and modes of regressive taxation. Moreover, they argue that carbon, especially carbon offsets, are an inherently "unregulatable commodity" 50 given the impossibility of assessing the "additionality" or whether the "savings" promised by offset projects represent a real change from what would have otherwise have happened without the project. They also show that markets display a "utopian faith in pricing", when in reality the carbon market, like all so-called "free" markets, is created and stabilized by law and regulation and this is a "political construc $(t)$, constituted by the constellation of social forces that dominate them". ${ }^{51}$ Pearse and Böhm also point to the problems of assuming that the emissions "saved" through forest sequestration can be equated to greenhouse gases emitted from the burning of fossil fuels because of the differences between "green" and "brown" carbon. Finally they critique the way carbon markets promote a system of technocratic rule managed by experts, and are an obstacle to alternative policies promoting decarbonization. ${ }^{52}$ Other analysts have suggested that "offsets" are a modern day form of medieval Church indulgences that enable dangerous forms of moral apathy to the ecological consequences of our actions. ${ }^{53}$ They have also demonstrated the ways in which carbon markets facilitate "carbon lock-in" and operate as a "dangerous distraction" production use and distribution. ${ }^{56}$ This imperative arises urgently in relation to the international climate regime. These perspectives have been articulated in numerous statements, including that by the newly

47 On 'green grabbing' see James Fairhead, Melissa Leach \& Ian Scoones, "Green grabbing: a new appropriation of nature?" (2012) 39:2 J Peasant Stud 237.

48 Corporate Europe Observatory, "'Saving' the Kyoto Protocol Means Ending the Market Mania" July 2001 cited in Arup Shah, "Climate Change Flexibility Mechanisms" Global Issues (2 April 2012), online: <http://www.globalissues.org/article/232/flexibility-mechanisms>.

49 Rebecca Pearse \& Steffen Böhm, "Ten reasons why carbon markets will not bring about radical emissions reduction" (2014) Carbon Management 1 [Pearse \& Böhm].

50 See also Larry Lohmann, "Regulation as Corruption in the Carbon Offset Markets" in Böhm \& Siddhartha Dabhi, supra note 44.

51 Pearse and Böhm, supra note 49 at 8.

52 Ibid..

53 Kevin Smith, Oscar Reyes \& Timothy Byakola, The Carbon Neutral Myth: Offset Indulgences for your Climate Sins (Amsterdam: Transnational Institute, Carbon Trade Watch 2007).

54 See for example Gregory C Unruh, "Understanding Carbon Lock-In” (2000) 28 Energy Policy 817.

55 Bullock, Childs \& Picken, supra note 43.

56 See for example Ronnie Hall, "REDD: The Realities in Black and White" (Friends of the Earth International, 2010); see also Lohmann, Carbon Trading, supra note 45; and Tamra Gilbertson \& Oscar Reyes, "Carbon Trading: How it works and why it fails" (Uppsala: Dag Hammarskjöld Foundation, 2009). 
formed Climate Justice Now! coalition at the Bali COP (2007) ${ }^{57}$ and Poznan COP (2008), "System Change not Climate Change - A Peoples' Declaration from Klimaforum09" (2009), ${ }^{59}$ the "Peoples' Agreement" from the "World Peoples' Conference on Climate Change" in Cochabamba (2010), ${ }^{60}$ the "Scrap ETS: No EU Emissions Trading Scheme" statement (2012) ${ }^{61}$ and the "Margarita Declaration on Climate Change" from the Social PreCOP meeting (2014). ${ }^{62}$ A social movement statement released in December 2014 to coincide with the Lima COP reads in part:

In the 'green' economy framework, its promoters aim to make us believe that 'sustainable economic growth' is possible and can be 'decoupled from nature' by using capitalist forms of production, or that it is feasible to 'compensate' or 'mitigate' contamination or destruction in one place by 'recreating' or 'protecting' another. Under an unjust and colonialist logic, the 'green' economy subjugates nature and autonomous peoples by imposing restrictions on the use of and control over their territories in order to fill the pockets of a few, even when communities possess the deeds to their land. ${ }^{63}$

Some environmental justice and Indigenous peoples' movements have developed the term "carbon colonialism" or " $\mathrm{CO}_{2}$ lonialism" to describe the operations of the international carbon market, and particularly such "carbon sinks". In 1991, the New Delhi based Centre for Science and Environment [CSE], in a report Global Warming in an Unequal World, described certain strategies that were being promoted to address climate change as perpetuating forms of "environmental colonialism". 64 Their report was in response to a World Resource Initiative report that suggested greenhouse gas reductions could be achieved if Asian households had less methane-producing cows and rice paddies. CSE criticized the failure to distinguish the "survival emissions" of the poor from the "luxury emissions" of the rich, and asked, "[j] ust what kind of politics or morality is this which masquerades in the name of 'one worldism' or 'high minded internationalism"," ${ }^{65}$ The term $\mathrm{CO}_{2}$ lonialism was also used by the

57 Carbon Trade Watch, "Climate Justice Now! Statement" Climate Justice Now (03 November 2008), online: $<\mathrm{http}: / /$ www.carbontradewatch.org/take-action-archive/climate-justice-now-statement-4.html $>$.

58 Carbon Trade Watch, "Radical New Agenda Needed to Achieve Climate Justice': Poznan Statement form the Climate Justice Now! Alliance", Climate Justice Now (12 December 2008), online:

$<$ http://www.carbontradewatch.org/archive/poznan-statement-from-the-climate-justice-now-alliance-2.html $>$.

59 "System Change not Climate Change - A Peoples' Declaration from Klimaforum09", online: <http://klimaforum.org/>,

60 World People's Conference on Climate Change and the Rights of Mother Earth, "People's Agreement of Cochabamba", (April 24, 2010), online: <https://pwccc.wordpress.com/2010/04/24/peoples-agreement/>.

61 See Chris Lang, "The EU Emissions Trading Scheme has failed: 'Time to Scrap the ETS"” REDD-Monitor, 16 April 2013, online $<$ http://www.redd-monitor.org/2013/04/16/the-eu-emissions-trading-scheme-has-failed-time-to-scrap-theets/>.

62 UNFCCC, "Margarita Declaration on Climate Change", online: $<$ http://newsroom.unfccc.int/unfcccnewsroom/margarita-declaration-social-movements-call-for-greater-participation/>.

63 No REDD in Africa Netword, "To Reject REDD+ and extractive industries", (1 December 2014), online: $<$ http://www.no-redd-africa.org/index.php/declarations/110-to-reject-redd-and-extractive-industries>.

64 Anil Agarwal \& Sunita Narain, "Global Warming in an Unequal World: A Case of Environmental Colonialism" (New Delhi: Centre for Science and Environment, 1991) at 1.

65 Ibid at 3. 
Norwegian NGO NorWatch in May 2000 in a report of that name, which examined two afforestation projects in Uganda by two different Norwegian companies. ${ }^{66}$

At the UNFCCC meeting in Lyon, France in September 2000, the International Indigenous Peoples' Forum on Climate Change (IIPFCC) released a statement, which said:

Our philosophy and cosmovision require us to condemn the inclusion of sinks in the Clean Development Mechanism (CDM). Sinks in the CDM would constitute a worldwide strategy for expropriating our lands, seas and territories and violating our rights that would culminate in a new form of colonialism. Through sinks projects, we would lose our right to manage traditionally our lands and become slaves of the carbon trade. Carbon trade-induced conflicts, such as violence for access to basic resources would endanger our survival as peaceful peoples of the land. ${ }^{67}$

At the COP6bis meeting in Bonn in 2001 the IIPFCC described these carbon sinks under Kyoto as a "new form of colonialisms and genocide". ${ }^{68}$ These critiques and the idea that the CDM could "constitute a dangerous tool for the expropriation of our lands and territories" November 2001 when the "Marrakesh Accords" Kyoto flexibility mechanisms, carbon trading, joint implementation and the CDM. This terminology was taken up by the report "No to $\mathrm{CO}_{2}$ lonialism! Indigenous Peoples' Guide: False Solutions to Climate Change" produced by the Indigenous Environment Network and other groups. ${ }^{71}$ Heidi Bachram has argued that "[e]missions trading therefore becomes an instrument by means of which the current world order, built and founded on a history of colonialism, wields a new kind of "carbon colonialism"”. ${ }^{2}$

\section{THIRD WORLD APPROACHES TO CLIMATE CHANGE}

One way in which these critiques have been taken up in international environmental law scholarship is through the language and frameworks of human rights. There is a growing body of scholarship that

66 Harald Eraker, " $\mathrm{CO}_{2}$ lonialism in Uganda" NorWatch Newsletter 5/00, online: <http://www.xn--framtidenivrehenderbxb.no/english/other/co2lonialism-in-uganda.html>. See also Centre for Science and Environment, "Carbon Colonialism: Cheap Fix: The Rush to Make Profits out of carbon-fixing engenders another kind of colonialism”, (25 October 2000) online: <http://www.cseindia.org/node/3136>.

67 "No to $\mathrm{CO}_{2}$ lonialism: Indigenous Peoples' Guide False Solutions to Climate Change" (Indigenous Environment Network, 2009) at 28.

68 Ibid.

69 Ibid.

70 “Marrakesh Accord”, Decision 2-14/CP.7, FCCC/CP/2001/13/Add.1, (21 January 2002).

71 Indigenous Environment Network, "No to CO2onialism! Indigenous Peoples' Guide: False Solutions to Climate Change", (2009), online: <http://www.uky.edu/ tmute2/nature-society/password-protect/nature-society-pdfs/IndigenousPeoples-Guide-Env.pdf $>$.

72 Heidi Bachram, "Climate Freud and Carbon Colonisation: The New Trade in Greenhouse Gases" (2004) 15:4 Capitalism, Nature, Socialism 5 at 19. 
brings a human rights analysis to bear on climate change and climate mitigation strategies. ${ }^{73}$ However, as Stephen Humphreys has argued, there is "no obvious hook for a human rights analysis of carbon markets" and numerous challenges in such an approach given the "fundamentally dissimilar" nature of these regimes. ${ }^{74}$ Francis Seymour has drawn attention to the human rights concerns that arise at the intersection of forest and climate change regimes. ${ }^{75}$ She highlights that the way in which forests become incorporated within mitigation strategies can have implications for the livelihoods and therefore for the realization of economic and social rights of forest-dependent communities. However, TWAIL scholars have expressed concerns about human rights becoming the main language of Third World resistance ${ }^{76}$ but also the way in which human rights discourses and framework can too easily be "manipulated to further and legitimize neo-liberal goals". ${ }^{77}$ There is therefore a sense that human rights approaches are not adequate to address underlying shifting dynamics of power that the expansion of new global carbon markets represent. Human rights approaches may provide tools for taming how new forms of international power over land authorized by the climate regime are exercised, however they have less to say about the underlying expansion of global power over land in the South through market mechanisms. To address such questions requires understanding how new forms of international authority over land are authorized by the climate regime. Below, I briefly canvas two other approaches that have been adopted by international environmental law scholars orientated to the South, namely examination and support of the positions of Third World states and promotion of legal principles such as burden sharing and differentiation, before outlining why these approaches provide limited theoretical tools to examine the effects of the increasing marketization of international climate governance.

Environmental issues such as control and fair sharing of natural resources were a key concern of Third World international lawyers in the 1960s and 1970s. However, as Usha Natarajan identifies, "environmental issues have not been a focus of Third World Approaches to International Law [TWAIL] scholarship since the acronym was first espoused in the 1990s". ${ }^{78}$ TWAIL approaches have demonstrated the continuing relevance of colonialism for international law, doctrine and practice and the

73 See in particular Stephen Humphreys, ed, Human Rights and Climate Change (Cambridge: Cambridge University Press, 2009) [Humphreys, Human Rights]. See also John Knox, Report of the Special Rapporteur on the issue of human rights obligations relating to the enjoyment of a safe, clean, healthy and sustainable environment, Human Rights Council, $31^{\text {st }}$ session, Agenda item 3, A/HRC/31/52 (1 February 2016) and Office of the United Nations High Commissioner for Human Rights, The Effects of Climate Change on the Full Enjoyment of Human Rights (30 April 2015).

74 Stephen Humphreys, "Conceiving justice: articulating common causes in distinct regimes" in Humphreys, Human Rights, ibid, 299 at 316 [Humphreys, "Conceiving Justice”].

75 Francis Seymour, "Forests, Climate Change and Human Rights: Managing Risks and Trade-offs" in Humphreys, Human Rights, supra note 73, 207.

76 Balakrishnan Rajagopal, International Law from Below: Development, Social Movements and Third World Resistance (Cambridge: Cambridge University Press, 2003).

77 BS Chimni, "Third World Approaches to International Law: A Manifesto" (2006) 8 Intl Community L Rev 3 at 3 [Chimni].

78 Usha Natarajan, "TWAIL and the Environment: The State of Nature, the Nature of the State and the Arab Spring” (2012) 14 Oregon Rev Intl L 177 at 182. 
need to democratize and decolonize both international law and international legal scholarship. ${ }^{79}$ Karin Mickelson has developed these insights in relation in relation to international environmental law [IEL] and shown that the colonial nature of international law is one that IEL shares. A key justification for colonization was "the dangling prospect of a new and seemingly inexhaustible source of resources", while historians such as Richard Grove have demonstrated the colonial origins of environmental discourses. ${ }^{81}$ Mickelson reminds us that environmental degradation does not arise in a vacuum. It frequently has certain benefits associated with it, and it obviously has certain costs. And all too frequently, some derive the benefits while others bear the costs. ${ }^{82}$

She argues that "a central, if not the central debate regarding the conceptual foundations" 83 of IEL are questions of North/South relations. More recently, Sumudu Atapattu and Carmen Gonzalez have also drawn attention to how IEL is a "site of intense contestation over environmental priorities, over the allocation of responsibility for current and historical environmental harm, and over the relationship between economic development and environmental protection". ${ }^{84}$ However, their analysis does not address the concern that IEL's increasingly market-orientated focus has become highly problematic, making it a site that arguably reinforces rather than ameliorates North/South hierarchies. In this article, my concern is not primarily with the fact that North/South tensions compromise the effectiveness of IEL, ${ }^{85}$ but rather that the focus on market-fostered efficiency in IEL undermines North/South equity.

To date, there has been remarkably little TWAIL scholarship on the issue of climate change, ${ }^{86}$ with the exception of Mickelson's work on climate justice ${ }^{87}$ and climate debt. ${ }^{88}$ There is, however, substantial and growing literature on climate justice, ${ }^{89}$ demonstrating the centrality of justice issues for climate

79 For more background on TWAIL see the editors' introduction to this special issue. See also James Thou Gathii, "TWAIL: A Brief History of its Origins, its Decentralized Network, and a Tentative Bibliography" (2011) 3:1 Trade L Dev at 26.

80 Karin Mickelson, "South, North, International Environmental Law, International Environmental Lawyers" (2000) 11 YB Intl Env L 52 at 56.

81 Richard Grove, Green Imperialism: Colonial Expansion, Tropical Island Edens and the Origins of Environmentalism, 1600-1860 (Cambridge University Press, 1996), see also Stephen Humphreys \& Yoriko Otomo, "Theorising International Environmental Law" (2014) LSE Law, Society and Economy Working Papers 9/2014.

82 Mickelson, supra note 80 at 59.

$83 \quad$ Ibid at 53.

84 Sumudu Atapattu \& Carmen G Gonzalez, "The North-South Divide in International Environmental Law: Framing the Issues" in Shawkat Alam et al, eds, International Environmental Law and the Global South (Cambridge: Cambridge University Press, 2015) 1 at 2.

85 Ibid.

86 On the lack of TWAIL engagement with international environmental law see Natarajan, supra note 78.

87 Karin Mickelson, "Beyond a Politics of the Possible? South-North Relations and Climate Justice" (2009) 10:2 Melbourne J Intl L 411.

88 Karin Mickelson, "Leading towards a Level Playing Field, Repaying Ecological Debt, or Making Environmental Space: Three Stories about International Environmental Cooperation" (2005) 43 Osgoode Hall LJ 137. See also Sundhya Pahuja, "Conserving the World's Resources" in James Crawford \& Martti Koskenniemi, eds, Cambridge Companion to International Law (Cambridge: Cambridge University Press, 2012) [Crawford \& Koskeniemi] at 398.

89 There is a vast literature on questions of climate justice: Jeremy Baskin, "The Impossible Necessity of Climate Justice?" (2009) 10:2 Melbourne J Intl L 424 and other articles in that Special Edition of the Melbourne Journal of International Law; Anna Grear, "Towards 'climate justice'? A critical reflection on legal subjectivity and climate injustice: warning signals, patterned hierarchies, directions for future law and policy" (2014) 5 Journal of Human Rights and the 
solutions, and also demonstrating why climate change needs to be a central concern for TWAIL scholars. Climate change "raises profoundly important questions about social justice, equity and human rights across countries and generations". 90 At the heart of climate justice is that "those most vulnerable to climate change are least responsible and have the least resources to adapt". ${ }^{91}$ Legal debates turn on questions of historical and continuing responsibility. ${ }^{92}$ Since 1950 , three-quarters of all emissions are attributable to developed states that host only one-fifth of global population. ${ }^{93}$ If historical emissions are taken into account, "North America exceeded its fair share of usage in the 1970s, and has been in carbon overdrive ever since". 94

In the context of the extreme inequalities in terms of responsibility for and vulnerability to climate change, within climate negotiations, countries from the South pushed for the inclusion of the principle of "common but differentiated responsibility" [CBDR] as central to the UNFCCC. ${ }^{95}$ The principle of CBDR and other norms of differential treatment recognize and respond to real historic, economic and political differences between states through the institution of different standards for differently situated states. $^{96}$ The Kyoto Protocol is widely considered to be the "clearest attempt to transform, activate and

Environment 103; Stephen Humphreys, "Climate justice: the claim of the past" (2014) 5 Journal of Human Rights and the Environment 134 [Humphreys, "Climate Justice"] and other articles in that Special Edition of Journal of Human Rights and the Environment; political economy: Bradley C Parks \& J Timmons Roberts, "Climate Change, Social Theory and Justice" (2010) 27 Theory, Culture and Society 134; J Timmons Roberts \& Bradley C Parks, "Ecologically Unequal Exchange, Ecological Debt, and Climate Justice: The History and Implications of Three Related Ideas for a New Social Movement" (2009) 50:3-4 Intl J Comp Soc 385; Ludvig Beckman \& Edward A. Page, "Perspectives on justice, democracy and global climate change" (2008) 17:4 Envtl Pol 527; informing policy approaches: Barbara Adams \& Gretchen Luchsinger, "Climate Justice for a Changing Planet: A Primer for Policy Makers and NGOs" (United Nations and UN Non-Governmental Liason Service, 2009) [Adams and Luchsinger]; Sonja Klinsky \& Hadi Dowlatabadi, "Conceptualisations of Justice in Climate Policy" (2009) 9 Climate Policy 88; from social movement perspectives: Patrick Bond, Politics of Climate Justice: Paralysis Above, Movement Below (Scottsville, SA: University of KwaZulu-Natal Press, 2012); Nicola Bullard, Ulrich Brand, Edgardo Lander \& Tadzio Mueller, ed, Contours of Climate Justice: Ideas for Shaping New Climate and Energy Policies (2009) [Bullard et al, Contours of Climate Justice]; Brian Tokar, "Towards Climate Justice" (2009) September Z-Magazine; Ulrich Brand et al, "Radical Climate Politics in Copenhagen and Beyond: From Criticism to Action?" in Bullard, et al, Contours of Climate Justice; Bertie Russell \& Andre Pusey, "Movements and Moments for Climate Justice: From Copenhagen to Cancun via Cochabamba" (2011) 11:3 ACME: An International E-Journal for Critical Geographies 15; Martina Austen \& Philip Bedall, "Climate Justice Point of Reference for a counter hegemony or nebulous empty phrase?", NoteFromBelow 29 July 2010 and Ashley Dawson, "Climate Justice: The Emerging Movement against Green Capitalism" (2010) 109:2 South Atlantic Quarterly 313 [Dawson].

90 "Human Development Report 2007/2008: Flighting Climate Change - Human Solidarity in a Divided World," 2007/2008, 22.

91 Humphreys, "Climate Justice" supra note 89 at 136.

92 Benito Müller, Niklas Höhne \& Christian Ellermann, "Differentiating (historic) responsibilities for climate change," (2009) 9:6 Climatic Policy 593.

93 Adams \& Luchsigner, supra note 89.

94 RT Pierrehumbert, "Cumulative Carbon and Just Allocation of the Global Carbon Commons" (2012-2013) 13 Chicago J Intl L 527.

95 UNFCCC, supra note 11, Article 3(1)

96 Lavanya Rajamani, Differential Treatment in International Environmental Law (Oxford: Oxford University Press, 2006) at 1 . 
operationalize CBDR from a legal concept to a policy instrument". ${ }^{97}$ It restricted legally-binding reductions of greenhouse gas emissions to developed countries only. Differential treatment is also evident in the provisions of the UNFCCC regime on climate financing, technology transfer, and capacity building. Unfortunately, since then, the principle of CBDR has been under sustained attack. It was not explicitly included in the 2011 Durban COP decision "to develop a protocol, another legal instrument or an agreed outcome with legal force under the Convention applicable to all Parties". Rather than a binary "firewall", developed countries are calling for a more "nuanced" understanding of differentiation in light of the increased emissions from some developing countries. ${ }^{98}$ This is reflected in the shift from the "topdown" Kyoto Protocol framework of legally-binding targets to the decentralized "bottom-up" approach in Paris 2015 where countries put forward nationally-determined targets. ${ }^{99}$ The erosion of CBDR is also achieved through differing interpretations of CBDR as either a historic, moral and legal "responsibility to pay"100 or a "pragmatic problem solving formula" based on "ability to pay" ${ }^{101}$ The failure of CBDR to "specify on what basis differentiation is to be made between countries - capability and/or culpability"102 - opens up a conceptual ambiguity whose resolution has material effects. Thus the basis of differentiation in CBDR is critical. There is a real risk that differentiation based upon Southern lack of capacity, rather than Northern responsibility, can authorize a reiteration of a colonial "dynamic of difference". ${ }^{103}$ If differential treatment is grounded in the greater current per capita and historical responsibility of developed countries for climate change, it operates as a redistributive measure to compensate and ameliorate the North's unequal appropriation of atmospheric space. Such an interpretation has been contested by United States negotiators who "categorically rejected" any "sense of guilt or culpability or reparations" for historical omissions, ${ }^{104}$ instead insisting on the need for all countries to "grow up" and take responsible future-orientated action on climate change. ${ }^{105}$ However, if the principle is grounded in a lack of "capacity" to take mitigation measures in the South, where such "capacity" is instead located in the North, a principle that focuses on lack of "capacity" risks becoming a pretext for significant interventions to assist with climate mitigation that themselves could be geared towards the expansion of neo-liberal market-based approaches and the regulation that enables them.

97 Christopher C. Joyner, in "Common but Differentiated Responsibilities" (2002) 96 Proc Am Soc Intl L 358.

98 Jutta Brunnée \& Charlotte Streck, "The UNFCCC as a negotiation forum: towards common but more differentiated responsbilities" (2013) 13:5 Climate Policy 589 at 590.

99 See the discussion in section III. D below.

100 See for example submissions by Tuvalu that "the allocation of responsibility for emission reductions should be based on historical emissions ... Annex I parties have contributed approximately $75 \%$ of cumulative global emissions of $\mathrm{CO}_{2}$. A global breakdown of historical responsibility can be represented as: Kyoto Annex I Parties 45.75\%, the United States 29.25\%, Non-Annex I Parties 25\%" cited in Thomas Deleuil, "The Common but Differentiated Responsibilities Principle: Changes in Continuity after the Durban Conference of the Parties" (2012) 21:3 RECIEL 271 at 273 [Deleuil].

101 Brunnée \& Streck, supra note 98 at 592; and Mickelson, supra note 80 at 70.

102 Rajamani, supra note 96 at 195. See Deleuil, supra note 100 at 272.

103 See Antony Anghie, Imperialism, Sovereignty and the Making of International Law (Cambridge: Cambridge University Press, 2007).

104 Cited in Patrick Bond, "Climate debt owed to Africa: What to demand and how to collect?" (2010) 2:1 African Journal for Science, Technology, Innovation and Development 83.

105 See for example Bryan Walsh, "China Shows It's Ready to Grow Up on Climate Change", Time (12 November 2014), online: $<$ http://time.com/3582178/china-us-climate-change-deal/>. 
While there is certainly a need to evaluate the framework of differentiation and how equitable burden sharing is achieved, especially in relation to the increasing greenhouse gas emissions of so-called BRICS countries (Brazil, Russia, India, China and South Africa), the continual focus on "capacity" rather than "responsibility" risks inequitable burden shifting on the part of developed states.

The development of carbon markets has also complicated Third World states' positions on climate mitigation. While some Southern states (particularly low-lying islands, Bolivia and some other South American states) have opposed these schemes, it is also the case that "developing country representatives have been leaders in the movement to expand carbon markets to new jurisdictions". ${ }^{106}$ The development of offset schemes has been promoted and supported by some Southern countries that see themselves as being able to capture some of the very unequally-distributed climate financial flow from these markets, ${ }^{107}$ including states that host the last remaining large forests, such as Papua New Guinea, Costa Rica and Indonesia. However, analytically a narrow focus on the interests of Third World states rather than their peoples can be limiting. As Anghie and Chimni highlight, Third World states often act against the interests of their peoples. They argue that a TWAIL "interpretive prism" must address international law from the "actualized experience of these peoples and not merely that of the states which represent them". ${ }^{108}$ Similarly, as Chimni has highlighted, the invocation of "national interests" by the ruling elite in Third World countries, who are increasingly part of an emerging "transnational ruling elite" can mask the establishment of a "global rule of transnational capital". 109 TWAIL scholars have been concerned to "identify and give voice to the peoples within Third World states - women, peasants, workers, minorities". ${ }^{110}$ Thus TWAIL scholars would do well to pay attention to the demands of social movements for climate justice described in the first part of this paper. ${ }^{11}$

\section{AUTHORITY AND MODES OF AUTHORIZATION IN THE UNFCCC}

\section{A. Constructing "Commonality"}

The preceding analysis of Third World state positions on climate change, TWAIL scholarly contributions on climate change, and the gaps therein, lead me to suggest that we need to move beyond an interrogation of how "common" responsibilities are to be shared and move instead towards an understanding of how the notion of "commonality" itself has been constructed through the UNFCCC. For this purpose, there are two aspects of the UNFCCC that reward scholarly attention. The first is the operation of a political/economic split within the climate regime, whereby the market or the "economic sphere" is tasked with operationalizing or implementing "political" objectives. The second is interrogating how the UNFCCC regime is authorized and how this authorization is effected in practice.

\footnotetext{
106 Pearse \& Böhm, supra note 49 at 4.

107 For a discussion of the unequal geographical distribution of the benefits of carbon markets to Third World countries see Tomilola Akanle Eni-Ibukun, International Environmental Law and Distributive Justice (London: Routledge, 2014).

108 Antony Anghie \& BS Chimni, "Third World Approaches to International Law and Individual Responsibility in Internal Conflicts" (2003) 2:1 Chinese J Intl L 77 at 78.

109 Chimni, supra note 77 at 6-7.

110 Anghie \& Chimni, supra note 108 at 83.

111 Rajagopal, supra note 76.
} 
On the first aspect, central to the operations of carbon markets is a split between the economic and the political spheres, where the setting of objectives is deemed to be "political" but their implementation is deemed to be "economic". TWAIL scholars have drawn attention to how any easy separation between the "political" and the "economic" sphere is "in fact impossible because what is defined as economic or political is itself a political question". ${ }^{112}$ The separation between objectives and their means of realization cannot be so easily compartmentalized. Moreover, a split between the political and the economic in international law provides authorization for different international institutions to address themselves to different aspects of an international issue. That is, in the climate context, this split authorized the UNFCCC as the primary forum for the negotiation of political commitments in relation to climate change, while the World Bank through its climate finance programs and its role as trustee of the Green Climate Fund is given significant power over the process by which Third World countries establish carbon trading schemes to support UNFCCC implementation.

On the second aspect of authority and modes of authorization, TWAIL scholarship has developed an important conceptual apparatus to interrogate the way in which "liberal" international law remains structured and organized by a colonial "dynamic of difference" that persists, despite formal decolonization, and is re-inscribed even as the discipline purports to renew itself. ${ }^{113}$ International law is thus implicated in the maintenance of a geopolitical power structure, the reproduction of a hierarchy of knowledge and the consequent differentiated distribution of material wealth. ${ }^{114}$ Sundhya Pahuja has argued that in the post-1945 era, the discourse, practices and institutions of development maintained this hierarchical "dynamic of difference" by inscribing a key lack to the South, but also by offering "a narrative of salvation centered on faith in economic growth". ${ }^{115}$ In this sense, development and growth function as "transcendent grounds" to international law and stabilize and give purported universality to its categories. This article explores how framing climate change as a "shared" or "common" challenge without contending with either the history of greenhouse gas emissions or the history of international law has the effect of reproducing patterns whereby "international law continuously disempowers the non-European world, even while sanctioning intervention within". "16 The legal response to climate change demonstrates how power differentials can be reproduced even in regimes that recognize the need for differentiated treatment to address structural inequalities. ${ }^{117}$ Carbon markets are an institutional response to the problem of climate change that establish new forms of authority over lands in ways that are experienced as colonial. They therefore provide a critical site to investigate how, even when the discipline of international law attempts to renew itself and aspires to establish new, future-orientated frameworks of co-operation based on a genuine "common concern", the structural power differentials central to the discipline nonetheless persist and get reproduced in the present, albeit in new forms. Below, I explore how reauthorization of international authority based on an invocation of "common

112 Sundhya Pahuja, Decolonising International Law: Development, Economic Growth and the Politics of Universality (Cambridge: Cambridge University Press, 2011) at 20.

113 Anghie, supra note 103.

114 Pahuja, supra note 112 at 37.

115 Ibid at 70.

116 Anghie, supra note 103 at 312. On climate change and history, see Humphreys, "Climate Justice", supra note 89.

117 On differentiated treatment in international environmental law see: Phillippe Cullet, Differential Treatment in International Environmental Law (London: Ashgate, 2003) and Rajamani, supra note 96. 
concern", especially when applied to a world deeply stratified by differential in power and access to resources, may reproduce and reorganize a colonial logic.

In discussing the doctrinal principle of "common concern", environmental law scholarship is generally caught between two modes of argumentation, dismay at the lack of concreteness of these general principles and defence of these principles as not simply normative or utopian. ${ }^{118}$ While there is an undercurrent of despair about the "lack of cooperation among states, lack of appropriate international institutions, a host of collective action problems, and free-riding [that] all render concerted efforts difficult, if not impossible", 119 there is also a sense that the idea of "common concern" offers possibilities of hope in international law, drawing on a "communitarian strain" in international law which may also be thought of as "the ethics of commons as community, or as "law-full" space". 120 Oscillating between a pessimistic assessment of practice and an optimism of principle, key responses have been that of searching for "any evidence in international law of ... the idea that there exists not just a community of necessity, but also of values", 121 while also asserting the necessity of "mutual interdependence" of all states within a "world order in which every sovereign state depends on the same global environment" is undeniable. ${ }^{122}$

In other fields, scholars and activists have criticized both the necessity and the desirability of such globalist thinking in relation to ecological problems, especially when devoid of consideration of power. ${ }^{123}$ Scholars in the field of political ecology warned of the dangers implicit in an imaginary of Earth as distinct bounded, blue-green sphere, a collective "life-boat" suspended in a vast universe, that demands collective responsibility and threatens collective vulnerability or annihilation. ${ }^{124}$ Such "one

118 For the latter see Jutta Brunnée, “International Environmental Law: Rising to the Challenge of Common Concern?" (2006) 100 Proceedings of the Annual Meeting (American Society of International Law) 307, in which she argues against the idea that international environmental law is neither "precise enough" nor "forceful enough to impose itself" at 308.

119 See for example ibid at 294: "Indeed, contemporary international law, based upon the precepts of sovereignty and territoriality of nation states, is ill-prepared for the challenges of climate change mitigation and adaptation."

120 Sundhya Pahuja, "Conserving the World's Resources?" in Crawford \& Koskenniemi, supra note 88, 398

121 Jutta Brunnée, "Common Areas, Common Heritage, and Common Concern" in Daniel Bodansky, Jutta Brunnée \& Ellen Hey, eds, The Oxford Handbook of International Environmental Law (Oxford: Oxford University Press, 2008).

122 See Jacqueline Peel, Science and Risk Regulation in International Law (Cambridge: Cambridge University Press, 2010) at 17, citing comments from President Judge Bedjaoui and Judge Weermantry in the International Court of Justice's Advisory Opinion on the Legality of the Threat or Use of Nuclear Weapons. See also Justice Weeramantry separate opinion in the Gabcikovo/Nagymaros where he wrote: "we have entered an era of international law in which international law serves not only the interests of individual States, but looks beyond them and their parochial concerns to the greater interests of humanity and planetary welfare".

123 See in particular, Wolfgang Sachs, ed, Global Ecology: A New Arena of Political Conflict (London: Zed Books, 1993); The Ecologist, Whose Common Future? Reclaiming the Commons (London: Earthscan, 1993). See also Arturo Escobar, "Beyond the Third World: Imperial Globality, Global Coloniality and Antiglobalisation Social Movements" (2004) 25:1 Third World Q 207.

124 See for example Kenneth E Boulding, "The Economics of the Coming Spaceship Earth" in H Jarrett, ed, Environmental Quality in a Growing Economy: Essays from the Sixth RFF Forum (Baltimore: John Hopkins University Press, 1966) at 3 and for critique of globalist Larry Lohmann, "Resisting Green Globalism" in Sachs, supra note 123); Vassos Argyrou, The Logic of Environmentalism: Anthropology, Ecology and Postcoloniality (New York: Berghahn Books, 2005); and Subhabrata Bobby Banerjee, "Who Sustains Whose Development? Sustainable Development and the Reinvention of Nature" (2003) 24:1 Organisation Studies 143. 
world" globalism, they argue, risks inflicting violence upon a globe deeply stratified in terms of power and access to resources, along lines of class, race and gender, and where the problem of climate change - its causes and effects - is deeply entangled in these very differentials. ${ }^{125}$ Thus, Jason Moore warns against a simplified attribution of causality to a collective humanity or "anthros", ${ }^{126}$ calling instead for a framing of the climate crisis not as a "global" or "common" problem but as a problem of global discrepancies - in wealth, consumption levels, power and vulnerability.

These critiques, while highly politically percipient of current configurations, are of more limited value for a re-constitutive move, or for ways of thinking about how a "commonality" could be constituted. Alongside his critique of "imperial globality" and "global colonity", Escobar's concern is directed at theorizing how social movements confronting a neo-liberal globalization might be seen as "constituting a new form of counter-hegemonic globalization" or "alternative globalisations" or "transmodernity". ${ }^{127}$ Addressing climate change, understood as "a symptom of a particular development path" and of "its globally interlaced supply-system of fossil energy"128 requires a similar transnational or globalized movement against the systems of fossil fuel dependency. It does not make sense to take a for/against position on whether climate change should be articulated as a matter of "common concern". Instead, the important political questions concern what types of commonality are envisioned, the ways in which commonality is patterned, the modes of being in common that are enacted, what modes of conduct are authorized, and what responsibilities are compelled.

\section{B. Carbon Markets and their Authorization}

In order to move beyond doctrinal debates about the principle of "common concern" as either "fact" or mere "aspiration", I argue that thinking about the invocation of "common concern" as a technology that authorizes a specific jurisdictional arrangement allows for a more careful examination of the kind of authority this invocation sets in motion, how it is directed, and how it is actualized. Moreover, it allows for more careful thinking about the different ways an international "common concern" can be ordered. That is, it directs thinking to the plurality of ways the nature of the international community can be imagined and the plurality of ways "international" can be ordered. ${ }^{129}$ This can be understood through examining three different sets of practices to address climate change - underpinned by ideas of utilitarian justice, distributive justice and what might perhaps best be described as a vision of "plurality in justices" $" 130$ - that are all in some way authorized by an invocation of "common concern".

125 Peter Newell, "Race, Class and the Global Politics of Environmental Inequality” (2005) 5:3 Global Environmental Politics 70 .

126 Jason W Moore, “The Capitalocene, Part I: On the Nature and Origins of Our Ecological Crisis”, online: (2014) Fernand Braudel Center, Binghamton University $<\mathrm{http}: / / \mathrm{www}$.jasonwmoore.com/uploads/The_Capitalocene_Part_I_June_2014.pdf $>$.

127 Escobar, supra note 123 at $223 \& 225$.

128 Thomas Cottier et al, "The Principle of Common Concern and Climate Change" (2014) 52 Archiv des Völkerrechts 293 at 314 .

129 Shaunnagh Dorsett \& Shaun McVeigh, Jurisdiction (Routledge, 2012), Ch 7.

130 Andrew Robinson \& Simon Tormey, "'Resisting 'Global Justice': Disrupting the colonial 'emancipatory' logic of the West" (2009) 30:8 Third World Q 1395. 
Carbon trading mechanisms, although promoted by specific interests, ${ }^{131}$ nonetheless are also authorized by a claim they act in and serve the public good. This claim continues to authorize carbon markets even as scholarship demonstrates how they do not and cannot achieve radical emission reductions ${ }^{132}$ and the utilitarian logic under which they operate then distributes harms and benefits unevenly. ${ }^{133}$ Conventional theory has rebutted a prevalent positivist notion that "economics has no $a$ priori notion of the collective or the common good." On the contrary, it stressed that "justifications for liberal markets must draw on moral claims about the nature of the common good, which must be more than merely utilitarian or calculative". ${ }^{134}$ The moral claim that grounds and legitimates carbon markets is that they will facilitate "emission reductions [taking] place where ever they are cheapest", 135 and that pursuing the aggregate least cost mitigation option serves the collective good, in that it allows for greater aggregate levels of ambition. ${ }^{136}$ For example, this moral claim underpins an Australian government fact sheet, "Global Actions - Facts or Fiction" responding to allegations that the use of offsets represents an abrogation of international responsibility to take domestic action. ${ }^{137}$ It argues that the international carbon market enables "countries to access cost-effective mitigation, wherever it occurs" and that this promotion of lowest-cost abatement options through the purchase of offsets rather than domestic reductions enables "deeper targets" to be committed to. The importance of geographical or contextual specificity is denied; rather, the argument's premise is that it "it makes no difference where emission reductions occur, provided that they do occur" and that there are neither scientific nor environmental reasons to favour abatement in one place over another. Its vision is of a utilitarian notion of justice that looks to an imagined aggregate in order to assess the overall common good. At stake therefore in critiques of carbon markets is not the absence of a "common concern" but the way the particular idea of "commonality" that underpins utilitarian idea of justice is organized.

A different structuring of "commonality" underpins ideas of climate action based on distributive justice norms, epitomized in "contract and convergence" frameworks such as that of greenhouse

131 See Peter Newell \& Matthew Paterson, Climate Capitalism: Global Warming and the Transformation of the Global Economy (Cambridge University Press, 2010). For a more critical perspective see Lohmann, Carbon Trading, supra note 45.

132 Pearse \& Böhm, supra note 49.

133 Scholars and activists have, often through case study examples, demonstrated the reproduction of structural injustice through these mechanisms, in that they allow for a deferral of climate action by polluters whilst often having negative social and environmental impacts on the communities where they are located. See for example: Lohmann, Carbon Trading, supra note 45; Böhm \& Dabhi, supra note 44; Rebecca Pearse \& Julia Dehm, “In the REDD: Australia's Carbon Offset Project in Central Kalimantan" (Friends of the Earth International, 2011). For these reasons Ashley Dawson describes carbon markets as "a specifically neo-liberal mode of biopower that hinges on allocating social death just as much as it does on guaranteeing the right to live" but where the categories of "human waste" or "superfluous humanity" are not uniform categories but depend upon "representational processes of marginalisation, subordination, and scape-goating", and "concentrated processes of race and class formation within particular national and subnational arenas". Dawson, supra note 89 , at 319.

134 William Davis, The Limits of Neoliberalism: Authority, Soveriegnty and the Logic of Competition (SAGE, 2014$)$ at 15.

135 NH Stern, The economics of climate change: the Stern review (Cambridge: Cambridge University Press, 2007) at xviii.

136 Ibid; see also Johan Eliasch, Climate change: financing global forests: the Eliasch review (Earthscan, 2008).

137 Department of Climate Change and Energy Efficiency, "Global Action: Fact or Fiction", online:

$<$ http://www.climatechange.gov.au/government/international/global-action-facts-and-fiction/use-of-offsets.aspx>. 
development rights. ${ }^{138}$ In these models, a "common objective" of climate mitigation is pursued, but in a differentiated fashion, where more significant mitigation is first required from those with the highest pollution levels, while often allowing for an increase in the emissions of those with low pollution levels. This vision of gradual convergence to a horizon of equal per capita emissions globally is read by some as the vision underpinning the principle articulated in the UNFCCC of CBDR. ${ }^{139}$ These principles of differentiated treatment are presented as both the means towards future co-operative international action but also an explicit acknowledgement of present persistent inequalities within the international.

Finally, in the practices of a growing transnational grassroots climate justice movement against fossil fuel extraction and in defense of more localized control over local resources, there is another patterning of commonality. These struggles, even though "place-based", are necessarily also globalized in addressing the transnational supply and logistics chains and financing processes that enable fossil fuel extractivism worldwide. What is "common" in these struggles is more a shared point of antagonism, rather than a shared future vision or aspiration to "commonality".

\section{C. "Common Concern" as a Jurisdictional Technology}

Doctrinally the principle of "common concern" is generally seen as not creating either specific rules or specific obligations but "establishes the general basis for the community concerned to act". ${ }^{140}$ There are two different accounts that can be given of this: one in which the expression of shared concern brings into being an international community, the other where the "international community" is imagined as a preexisting entity. In jurisdictional terms we could describe this as two rival accounts of the international, one in which the international domain is given shape by a free meeting, ${ }^{141}$ and another that "shape(s) the international domain around forms of cosmopolitan order that treat the international domain as having an independent existence". ${ }^{142}$ This second account of international ordering is reflected in most doctrinal discussions of the principle of "common concern" in international environmental law. In such accounts the "international" is already structured, and this prior background structuring implicitly determines what actions can be taken pursuit to an expressed "common concern". Examining the invocation of "common concern" as a jurisdictional technology allows for a more nuanced understanding of how authority pursuant to a "common concern" is actualized differentially in the North and South. In contrast to the earlier concept of "common interest" in international environmental law that was directed towards established international jurisdiction over shared resources or areas beyond the jurisdiction of any nation states, ${ }^{143}$ the invocation of "common concern" in the UNFCCC pertains to matters spatially within nation states. The effect of this designation, as Kiss and Shelton outline, is it removes the topic of concern from a state's exclusive jurisdiction and makes it a

138 Paul Baer et al, "Greenhouse Development Rights: towards an equitable framework for global climate policy" (2008) 21:4 Cambridge Rev Intl Affairs 649.

139 See Rajamani, supra note 96.

140 Alexander Kiss "The Common Concern of Mankind" 27 Env Pol L cited in "Second report on the protection of the atmosphere by Shinya Murase, Special Rapporteur" International Law Commission, $67^{\text {th }}$ session, A/CN.4/681 (2 March 2015), fn 97.

141 Dorsett \& McVeigh, supra note 129 at 118.

142 Ibid.

143 Dinah Shelton, “Common Concern of Humanity” (2009) 39:2 Env Pol L 83 
"legitimate matter for international regulation". 144 As such, the designation of a matter of "common concern" could be understood as a technology that authorizes an international jurisdiction over that domain of concern. Nonetheless such a designation does not remove a state's sovereignty over the topic in question. Instead it establishes a complicated balancing between international and domestic jurisdictional authority over the domain of common concern, whereby the right of the international community to act is balanced against national sovereignty, and national exclusive jurisdiction is subject to international obligations. ${ }^{145}$

This authorization of international jurisdiction and this complicated balancing between international and national jurisdictional authority over the domain of common concern is necessarily formally global in space. That is, emissions of greenhouse gases in the United States or in Senegal are similarly incorporated in this domain of this concern. However, TWAIL scholarship has importantly demonstrated the much more "porous" nature of Third World sovereignty in relation to international intervention; that is, the way in which for some countries sovereignty acts as a strong "bulwark" against international obligations, while for other countries sovereignty provides only a very limited "shield" against imposed international forms of action. ${ }^{146}$ That is, the invocation of "common concern" establishes an international jurisdiction that is formally global but differentially actualized.

This analysis of how an international jurisdiction ordered around a "common concern" is differentially actualized and can be differentially materialized has three key implications. Firstly, it points to how countries in the South can be differently compelled to take action pursuant to a "common concern" if they are subject to conditionality through debt or in need of climate finance, than countries of the North who are providers of this finance. Secondly, it points to a responsibility gap, where those countries responsible for the greatest proportion of current and historical emissions are also least subject to an international jurisdiction pursuant to a "common concern" about the climate. Finally, it explains how countries of the South can be differentially compelled to adopt specific forms of action pursuant to the invocated "common concern", which in this instance has manifested in the establishment of new commodities of carbon and new markets for their circulation.

To understand the forms of action authorized by an invocation of "common concern", it is necessary to first problematize the ways in which climate change coalesces into specific representations as "scientific phenomenon", as an "object" of governance and as a "problem" for international law. ${ }^{147}$ The modes by which the "problem" of climate change is framed is not neutral; they are themselves effects of specific assemblages of material and discursive power, that create a "field of intelligibility" that has the effect of enabling certain forms of actions and actors while constricting and marginalizing others. ${ }^{148}$

\footnotetext{
144 Alexandre Charles Kiss \& Dinah Shelton, Guide to International Environmental Law (Martinus Nijhoff Publishers, 2007) at 14.

145 Ibid.

146 Anghie, supra note 103.

147 Fleur Johns, Non-Legality in International Law: Unruly Law (Cambridge: Cambridge University Press, 2013 ) at 164.

148 Bertie Thomas Russell, Interrogating the Post-Political: The Case of Radical Climate and Climate Justice Movements (PhD Thesis, University of Leeds, 2012) [unpublished] at 15. See also Sheila Jasanoff, "A New Climate for Society" (2010) 27:2-3 Theory, Culture and Society 233.
} 
Contestation around the framing of problems is simultaneously contestation over the form of jurisdiction that is enlivened in response and what actions, responses and actors are authorized. ${ }^{149}$

The specific understanding of the problem of climate change at play in the UNFCCC is evident in how the primary objective of the Convention is articulated as the "stabilization of greenhouse gas concentrations in the atmosphere at a level that would prevent dangerous anthropocentric interference with the climate system". ${ }^{150}$ Crucially, however, the objective also iterates that "such a level should be achieved ... [in a manner] to enable economic development to proceed in a sustainable manner". ${ }^{151}$

This framing of the "problem" of "common concern" has two key implications for directionality in which it is expressed, spatially and temporally. Firstly, the concern is directed "outward" not "inward", that is primarily concerned with the direct effects that produce climate change - GHG emissions - rather than their causes, the "human activities [that] have been substantially increasing the atmospheric concentration of greenhouse gases". ${ }^{152}$ As such, the regulatory objectives are directed not towards addressing these causes, such as fossil fuel extraction, but towards addressing the aggregate level of GHG emissions, without distinction for the social context in which these emissions arise. As such, the objectives of the agreement are translated from a political goal and antagonistic of transforming these causes and "overcoming fossil fuel dependence by entrenching a new historical pathway" to a more technical goal of achieving "measurable, divisible greenhouse-gas "emission reductions". ${ }^{153}$ Moreover, there are jurisdictional implications of this framing. Positing the object of regulation as atmospheric build-up of GHG calls for the extension of new forms of supranational regulation, rather than an examination of the ways in which international law is already "complicit in creating the climate crisis" through its "facilitating of an oil-based, capitalist economy." 154 Secondly, the concern is directed into the future, rather than a problem of the connections between the past, present and future. ${ }^{155}$

The dual objective of "greenhouse gas stabilization" alongside the continual pursuit of economic growth demonstrates the quasi-transcendental positing of economic growth in relationship to international law, a positioning that prevents the regime from addressing the tensions between economic growth and ecological limits, or economic growth as a problem for sustainability. Within the UNFCCC regime, tensions between ecological limits and imperatives of economic growth were mediated by a third term, efficiency. This manifested itself differently in the North and South: as a program for

149 See also Sara Dehm, "Framing International Migration” (2015) 3:1 London Rev Intl L 133.

150 UNFCCC, supra note 11, Article 2. For an interesting recent example of this, see the ILC programme of work on the 'protection of the atmosphere' and the clear jurisdictional boundary-work that was done to frame the scope of the ILC's work so as not to interfere with the UNFCCC's jurisdiction over international co-ordination to address climate change mitigation.

151 UNFCCC, ibid, Article 2.

152 UNFCCC, ibid, preamble.

153 Larry Lohmann, "When Markets are Poison: Learning about Climate Policy from the Financial Crisis" (The Corner House, 2009) [Lohmann, "Financial Crisis"].

154 Shirley V Scott, "Is the Crisis of Climate Change a Crisis for International Law: Is International Law too Democratic, too Capitalist and too Fearful to Cope with the Crisis of Climate Change?" (2007) 14 Australian Intl LJ 31 at 32, 35-36.

155 Anne Orford, “On international legal method” (2013) 1:1 London Rev Intl L 166 at 176. 
"ecological moderation" in the North ${ }^{156}$ and as a program of "sustainable development" in the South. ${ }^{157}$ The effects of this imperative of efficiency were two-fold, determining both the quantification of targets and the means by which they could be achieved. The targets taken on in the 1997 Kyoto Protocol, of a five percent reduction of developed states' greenhouse gas emissions from their 1990 levels, were primarily a result of political negotiation. However, the imperative of aggregate economic efficiency underpinned the three "flexibility mechanisms" introduced in the Kyoto Protocol, namely carbon trading, ${ }^{158}$ and the two project-based offset mechanisms "CDM"159 and joint implementation. They are based on the premise that mitigation should take place where it is cheapest to do so. A condition of possibility for this argument is a prior understanding of climate action in standardized and substitutable terms: that is, the ability to think of different actions contributing to climate change as "equivalent" in some way and therefore easily exchangeable. As a result, climate action, and the myriad ways in which ecological change unfolds, must become expressible, measureable and assessable in terms of a "general equivalent". Within this imaginary, it is the one tonne of carbon dioxide equivalent $\left(1 \mathrm{tCO}_{2} \mathrm{e}\right)$ which operates as the "general equivalent" and this rubric becomes a means by which mitigation action in one place can be compared to that in another and its contribution to a global aggregate goal can be evaluated. This substitutability of emission reductions, or the ability to render very different actions commensurable through the rubric of $\mathrm{CO}_{2} \mathrm{e}$, is the outcome of various techniques that make it possible to abstract climate mitigation actions from their "place, technology, history and greenhouse gas type". 160

This positioning of $1 \mathrm{tCO}_{2} \mathrm{e}$ as a "general equivalent" capable of measuring the quality of mitigation action relies first upon defining mitigation objectives in aggregate terms as specific global $\mathrm{CO}_{2}$ reduction targets, that is defining mitigation in terms of achieving "measurable, divisible greenhouse-gas emission reductions" "161 and aggregate global targets. Larry Lohmann has problematized this assumption, suggesting more political ways of understanding climate mitigation in terms of situated and contextual transitions towards decarbonization or "overcoming fossil fuel dependence by entrenching a new historical pathway". ${ }^{162}$ In this formulation there remains a global objective, that of social transformation towards decarbonization; however, there is no way of measuring contextual and situated progress toward this objective in standardized terms or rendering different actions towards this objective commensurable. In fact, transformation towards decarbonization requires precisely different actions in different places, because social and ecological changes unfold in contextual, situated and messy ways, and the assessment of its unfolding is only measurable against a unique and path-dependent envisioned trajectory being pursued in each situated context.

156 On ecological modernisation see Arthur PJ Mol \& David A Sonnenfeld, "Ecological Modernisation Around the World: An Introduction" in Arthur PJ Mol \& David A Sonnenfeld, eds, Ecological Modernisiation around the World:

Perspectives and Critical Debates (London: Frank Cass, 2000) 3

157 For a critical perspective on sustainable development see Arturo Escobar, Encountering Development: The Making and Unmaking of the Third World (Princeton, NJ: Princeton University Press, 1995) at 192-211.

158 Kyoto Protocol, supra note 28 at Article 17.

159 Ibid at Article 12.

160 Lohmann, "Financial Crisis", supra note 153 at 29.

161 Ibid.

162 Larry Lohmann, "Uncertainty Markets and Carbon Markets: Variations on Polanyian Themes" (2010) 15:2 New Political Economy 225 at 237. 


\section{The Political and Economic Organization of the International}

The construction of the "generalized equivalent" that carbon markets depend upon, and what Larry Lohmann has called "endless algebra of the carbon markets"163 they give rise to, are constitutively dependent upon a prior conceptualization of climate action to be carried out by the "international community", imagined as an entity, in aggregate terms. However, the inverse is not true. The conceptualization of climate action in aggregate terms does not necessarily give rise to the utilitarianism of markets. Instead, positing the aggregate climate action that the "international community", imaged as an entity, could also open up a political space within the international for contestation about the equitable distribution of burdens. In the climate regime this contestation has happened through the principle of CBDR, a burden-sharing principle premised on co-operation towards a collective goal.

In more recent years, however, the, trajectory of the international regime has been towards the dismantling of this political organization of "common concern". The form of the international regime has been transformed from the "top-down" Kyoto structure of aggregate targets, divided on a principle of equity, to a "bottom-up" pledge and review model of voluntary commitments based on "national circumstances". The emergence of a more "bottom up" form of climate agreement can be seen in the Bali Action Plan of 2007. ${ }^{164}$ However, it was the highly controversial Copenhagen Accord that first articulated a "pledge and review" framework for mitigation. ${ }^{165}$ While it was strongly opposed by many developing countries in 2009, this model of "bottom up" mitigation was confirmed in the Cancun Agreement on Long-term Co-operative Action ${ }^{166}$ and in the negotiations in the Ad-hoc Working Group on the Durban Platform for Enhanced Action towards a Paris agreement to be reached in 2015. At the Warsaw COP, countries were asked to make preparations for submitting their "international nationally determined contributions", ${ }^{167}$ while the Lima Call for Climate Action put forward more detailed modalities and specifications for these. ${ }^{168}$ The mitigation pledges in the Paris Agreement are structured around "bottom-up" "nationally determined contributions" put forward by countries.

This shift from a "top-down" to a "bottom-up" model has two key implications. Instead of an aggregate international goal divided on the basis of political contestation around principles of equity, countries now put forward their own voluntary and "nationally determined" contributions. What is lost in this formal decentralization of mitigation commitments is an internationally grounded normative basis from which to make an assessment of the justice of the proposals put forward, that is, whether commitments as stated represent a "fair share" or an equitable distribution of the burdens of responding to the climate crisis. A civil society review found that the ambition of developed countries articulated in their "national determined contribution" pledges fall well short of what could be considered their "fair share", with the United States' and the European Union's pledges representing only about a fifth of what could be considered their "fair share". ${ }^{169}$ Moreover, while there is an internationally articulated

163 Larry Lohmann, "The Endless Algebra of Climate Markets” (2011) 22:4 Capitalism, Nature, Socialism 93.

164 Decision 1/CP.13, "Bali Action Plan” FCCC/CP/2007/6/Add.1 (14 March 2008).

165 Decision 2/CP.15, "Copenhagen Accord” FCCC/CP/2009/11/Add.1 (30 March 2010).

166 Decision 1/CP.16, "The Cancun Agreements: Outcome of the work of the Ad Hoc Working Group on Long-term Cooperative Action under the Convention" FCCC/CP/2010/7/Add.1 (15 March 2011).

167 Decision 1/CP.19 'Further advancing the Durban Platform' FCCC/CP/2013/10/Add.1 (31 January 2014).

168 Decision 1/CP.20, 'Lima Call for Climate Action' FCCC/CP/2014/10/Add.1 (2 February 2015).

169 Civil Society Review, Fair Shares: A Civil Society Equity Review of INDCs: Summary (October 2015) online: 
(inadequate) "shared objective", namely that of limiting warming to an increase of 2 degrees Celsius, ${ }^{170}$ annual reports released by the UNEP each year show a growing "emissions gap" between the decentralized, national commitments and what would be necessary to achieve these objectives. ${ }^{171}$ In this process of formal decentralization of the regime, a different model of the "international" community has appeared: the UNFCCC is focused less on the distributive struggles over the equitable burden sharing towards a shared international goal, and more on the structuring of a specific economic environment that "incentivizes" national action.

\section{MOVING TOWARDS ALTERNATIVE COMMONALITIES}

There have been increasing civil society protests directed at the UNFCCC processes. In 2007 Indigenous peoples protested outside the UNFCCC after being excluded from a civil society meeting with the UNFCCC Secretary, wearing gags that read "UNFCCC". ${ }^{172}$ Similarly, at the Poznan COP in 2008, Indigenous peoples protested after reference to their rights was excluded on a decision relating to REDD.$+{ }^{173}$ The protests that occurred at the 2009 Copenhagen COP were widely seen as crystallizing the climate justice movement. "Hopenhagen", as it was sometimes called, was widely promoted as the summit that would "determine humanity's future" and was attended by 115 heads of state and over 40,000 people from governments, NGOs, IGOs, media and UN agencies. Outside, in the streets of Copenhagen, over 100,000 people marched, carrying banners with slogans including "nature doesn't compromise" and "climate justice now". They were calling on the international community, as represented in this institution, to live up to the promise of "common concern" animating the Convention, to be future-oriented and develop a legally binding treaty that recognized the intra-generational justice questions central to the climate crisis - the North's historical and ongoing responsibility for its causes and the extreme vulnerability of communities in the Global South. The summit reached its unsatisfactory conclusion, marred by low ambition, corporate capture and the predominance of neoliberal market-oriented solutions. It produced the controversial and non-binding "Copenhagen Accord" that was "noted" by the COP in an eleventh hour, backroom negotiation. Thousands of activists from the North and the South marched, not to call on the summit to act, but to protest its form of action, as 200 conference delegates simultaneously staged a walk-out with the aim of collectively holding a separate People's Assembly for Climate Justice. This protest has been read as "indicating a new form of political

\footnotetext{
$<\mathrm{http}: / /$ civilsocietyreview.org/> at 3 .
}

170 For many this is an aggregate goal that already sacrifices the interests of many; delegates at Copenhagen described an agreement with this objective as a 'suicide pact' for parts of Africa and low-lying island states. See John Vidal \& Jonathan Watts, "Copenhagen closes with weak deal that poor threaten to reject" The Guardian, (19 December 2009), online: <http://www.theguardian.com/environment/2009/dec/19/copenhagen-closes-weak-deal>.

171 United Nations Environment Programme, "The Emissions Gap Report 2014” (UNEP, 2014), online: $<$ http://www.unep.org/publications/ebooks/emissionsgapreport2014/portals/50268/pdf/EGR2014_LOWRES.pdf>.

172 See Climate \& Capitalism, "Indigenous peoples protest exclusion from Bali talks" (7 December 2007), online: $<$ http://climateandcapitalism.com/2007/12/07/indigenous-peoples-protest-exclusion-from-bali-talks/>.

173 Chris Lang, “No rights, no REDD': Indigenous Peoples protest in Poznan” REDD-Monitor, (9 December 2008), online: $<$ http://www.redd-monitor.org/2008/12/09/no-rights-no-redd-indigenous-peoples-protest-in-poznan/>. 
engagement" described as "diagnonalism", breaking down "inside/outside" and "for/against" distinctions by fermenting physically and intellectually a "third space". ${ }^{174}$

COP 16 (2010) in Cancun could be seen as the site where these possibilities closed down. The "consensus" decision was pushed through despite the following objections from Bolivia: "[a]n accord where only the powerful win is not a negotiation, it is an imposition" and that "[a] so-called victory for multilateralism is really a victory for the rich nations who bullied and cajoled other nations into accepting a deal on their terms". ${ }^{175}$ The observer status of vocal critics of the negotiations was also revoked, with Tom Goodtooth, the executive director of the Indigenous Environment Network temporarily blocked from entering. ${ }^{176}$

At the Warsaw COP in November 2013, one day prior to the scheduled completion of talks, civil society groups including Friends of the Earth International, the International Trade Union Confederation, PanAfrican Climate Justice Alliance, Bolivian Platform on Climate Change, Jubilee South, 350.org, Greenpeace, WWF, Oxfam, ActionAid and others, walked out of the negotiations. Their message, "polluters talk - we walk", pointed to what they described as the "toxic influence of dirty energy companies on the climate talks and the positions of many national governments". ${ }^{177}$ In particular, they pointed to the decision of the Polish government to invite sponsorship from large polluters including PGE, Alstom, LOTOS, ArcelorMittal, BMW, General Motors and Emirates Airlines, ${ }^{178}$ and the Polish Ministry of Economy co-hosting with the World Coal Association an "International Coal and Climate Summit". ${ }^{179}$ In a statement, campaign group 350.org wrote:

By walking out of COP19, we're walking into a fight with the real enemies to progress: the coal, oil and gas companies that have a stranglehold over our governments and economy. It's time to stop sitting in negotiating halls and stand with the Philippines and

174 Ibid at 21.

175 Climate \& Capitalism, "Bolivia: Cancun deal is hollow and false; its cost will be measured in human lives", (11 December 2010), online: <http://climateandcapitalism.com/2010/12/11/bolivia-cancun-deal-is-hollow-and-false-its-costwill-be-measured-in-human-lives $/>$.

176 See "Prominent Indigenous Environmental leader Tom Goodtooth blocked from UN Climate Talks" Democracy Now, (9 December 2010), online: <http://www.democracynow.org/2010/12/9/prominent_indigenous_environmental_activist_blocked_from_un>.

177 "Polluters talk, we walk: Mass walk out of corporate-captured climate talks in Poland", (21 November 2013), online: $<$ https://www.foeeurope.org/polluters-talk-we-walk-211113>.

178 "Open Letter Calling for rules to protect the integrity of climate policy-making from vested corporate interests", $(21$ November 2014), online: <http://corporateeurope.org/blog/open-letter-calling-rules-protect-integrity-climate-policymaking-vested-corporate-interests $>$ [“Open Letter"].

179 Corporate Europe Observatory describing the 'unprecedented corporate influence' as having a 'detrimental impact on progress in the talks' ('Polluters talk, we walk' Corporate Europe Observatory,

$<\mathrm{http}$ //corporateeurope.org/blog/polluters-talk-we-walk> ['Polluters talk, we walk']). In an Open Letter 75 civil society groups wrote that "at risk are both our climate and the integrity of the UNFCCC as a multilateral process to tackle climate change", “Open Letter" supra note 178). See also Ortiz et al "How Corporations Rule: Part 4: Anglo American's dirty energy lobby and its false climate solutions" (Corporate Europe Observatory, Friends of the Earth International and Transnational Institute, 2014), online:

$<$ https://www.tni.org/files/download/17_foei_corporate_capture_report_eng_mr.pdf $>$. 
millions more who are calling for real climate action in the aftermath of Typhoon Haiyan. ${ }^{180}$

Similar concerns were raised that the Paris COP 21 in December 2015 would represent yet another "corporate COP" and generated significant civil society opposition. ${ }^{181}$ Radical climate justice groups debated the need to "shut down" the "conference of the polluters" ${ }^{182}$ Activists promised "the largest mass civil disobedience climate justice action that we have ever seen in Europe" blocking streets and infrastructure in Paris if certain "red lines" necessary for a livable planet are crossed in the negotiations. ${ }^{183}$ However, in November 2015, the French government declared a state of emergency in the wake of terrorist attacks and banned protests, marches and other "outdoor activities" during the Paris summit. ${ }^{184}$ Nonetheless, climate activists defied this ban on protest throughout the conference and thousands took to the streets after the final text was released. ${ }^{185}$

For grassroots climate justice movements, however, the modes of authority and authorization described above pose a dilemma about whether to engage with the UNFCCC negotiation process. This dilemma arises precisely because of the impossibility of letting go of the promise of enacting a form of international "common concern" capable of urgently addressing the crisis that is invested in these institutional forums. However, holding to this promise risks authorizing conceptions of "common concern" that might do violence to those most marginalized.

The rhetoric and reality of the 2014 Climate Summit and Peoples' Climate March provides an illustration. The Peoples' Climate March was called for by UN Secretary-General Ban Ki-Moon himself and was held two days before the September 2014 UN Climate Summit. ${ }^{186}$ It brought 400,000 people to the streets of New York, and a further 2,646 solidarity rallies were held in 162 countries around the world as part of the largest-ever popular mobilization about climate change. The rally foregrounded Indigenous peoples and posited them as at the "frontlines of crisis and forefront of change". The banner carried by the Indigenous Environment Movement at the front of the march read "Respect Indigenous Peoples' Rights: End $\mathrm{CO}_{2}$ lonialism”.

\footnotetext{
180 "Polluters talk, we walk", supra note 177.

181 Environmental Action, "More than 224,000 call on UNFCCC to kick big polluters out of climate policy", online: $<$ http://environmental-action.org/blog/kick-big-polluters-climate-policy/>.

182 Patrick Bond, "Climate Movement Across the Movements" CounterPunch, (31 March 2015), online: $<$ http://www.counterpunch.org/2015/03/31/a-climate-movement-across-the-movements/>.

183 Arthur Nelson Brussels, "Activists promise largest climate civil disobedience ever at Paris summit", The Guardian, (8 October 2015), online: <http://www.theguardian.com/environment/2015/oct/08/activists-promise-largest-climate-civildisobedience-ever-at-paris-summit>.

184 For a discussion and critique of this ban on protest see Naomi Klein, "What's really at stake at the Paris climate conference now marches are banned", The Guardian, (20 November 2015), online: < http://www.theguardian.com/commentisfree/2015/nov/20/paris-climate-talks-protesters-hollande-violence>.

185 "Photos: Thousands Protest in Paris to Urge Climate Action" Inside Climate News, (12 December 2015), online: $<$ http://insideclimatenews.org/news/12122015/photos-paris-cop21-climate-change-protest-red-lines $>$.

186 See UN Climate Summit website, <http://www.un.org/climatechange/summit/>.
} 


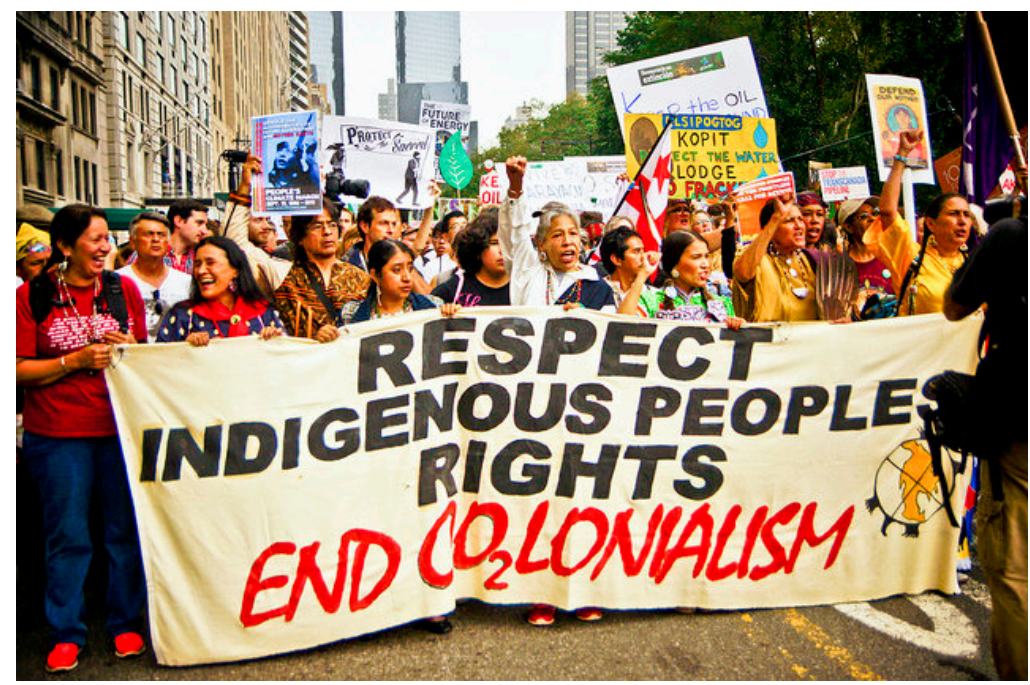

Figure 1: "End $\mathrm{CO}_{2}$ lonialism" picture taken on 24 September 2014 at the Peoples' Climate March by Joe Brusky (Joe Brusky Photography / Light Brigading) Image used with permission.

Inside the UN Climate Summit, the march was invoked by assembled leaders as authorizing their power to act in the name of the peoples of the world. For Ban Ki-moon, the march was a message to which he "hope[d] the leaders of the world listened", while President Obama reflected that "as citizens of the world keep marching we cannot pretend that we don't hear their call". Leaders produced specific narratives of the march so that it operated as a "site or space of enunciation" through which their own authority was given "shape" and "set in motion". ${ }^{187}$ While the summit carefully mobilized its representations of the march as a "call to action" in order to reground its renewed authority as a site of promise capable of acting on a "common concern", these invocations necessarily required invisibilization of these other voices and "subjugated knowledges" whose critique was directed at the form of action taken and the forms of commonality imagined. That is, even as institutional power is authorized in the name of a global need for action, and particularly in the name of those presented as most vulnerable, the actual voices and perspectives of "frontline" communities about the types of action that should be pursued are simultaneously erased and dismissed.

The summit was attended by 100 heads of state and government and 800 leaders from business, finance and civil society. Its objective was to provide "political momentum for a meaningful universal climate agreement in Paris in 2015" to replace the Kyoto Protocol. ${ }^{188}$ The rhetoric at the summit presented its activities in "world-changing" terms: at the opening ceremony, the UN Secretary-General

187 Peter Rush, "An Altered Jurisdiction: Corporeal Traces of Law” (1997) 6 Griffith L Rev 144, 150, see discussion of this in relation to international law in Sundhya Pahuja, "Laws of encounter: a jurisdictional account of international law" (2013) 1:1 London Rev Intl L 63.

188 The Kyoto Protocol's first commitment period (2008-2012) recently expired and, pursuant to the Doha Agreements, a second commitment period was agreed to (2012-2020); however, this Amendment has yet to receive sufficient ratifications to be legally binding. 
told participants "[w]e are not here to talk but to make history". ${ }^{189}$ For all the hype, the summit delivered little in the way of new climate action beyond the reiteration of old commitments and the launch of problematic initiatives. The key outcome of the summit was to confirm a specific trajectory towards climate action - from the summit to the Lima and Paris UNFCCC meetings - and call for renewed public faith in this trajectory. Leaders at the summit continuously sought to ground the inevitability and centrality of their own authority on the basis that they were acting on behalf of a "common concern", while simultaneously excluding specific voices, perspectives and knowledges in this grounding through purporting to act in their name.

These debates about how to engage with international legal processes and institutional spaces to address climate change echo broader debates in international law about the relationship between critique and transformative change, and the relationship between "reformist" and "revolutionary" positions. 190 However, a jurisdictional focus helps redirect the question: instead of asking whether to engage with or disrupt the UNFCCC, we can instead focus on the question of what type of international common concern could genuinely address the climate crisis.

Reflecting on climate justice engagements with the Copenhagen COP, Bertie Russell, Andre Pusey and Leon Sealey-Huggins argue that it does not make sense to posit the same easy "inside/outside" distinction in relation to the UNFCCC as movements had done in relation to the WTO. Nor did it make sense to articulate simple alliances based on who was "against" or "for" climate change. Instead, movements were confronted with a "complex institutional process that pulled together NGOs and governments around the myth that they were there to "solve climate change"". 191 A more complex division arose between those climate justice activists who maintained faith in the myth that the UNFCCC could solve climate change, or for strategic purposes continued to invest in lobbying and engagement to actualize this myth; and those who saw the COP as "an attempt to inaugurate a new round of 'green' capitalist accumulation and to establish new regimes of political legitimacy" 192 and therefore as something one should position oneself antagonistically against. ${ }^{193}$ Elsewhere, prominent activist/scholar Larry Lohmann, who has been at the forefront critical discussions of carbon markets, self-reflectively ruminated upon the limitations of this critical focus on "false solutions" in the face of the urgent need to build the political power of grassroots movements for climate justice. ${ }^{194}$ He suggests

189 President Obama's 2014 UN Climate Summit Speech, 23 September 2014, online: <https://www.youtube.com/watch-

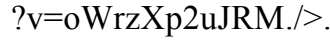

190 Luis Eslava \& Sundhya Pahuja, "Between Resistance and Reform: TWAIL and the Universality of International Law" (2011) 3:1 Trade, Law and Development 103.

191 Russell \& Pusey, supra note 89 at 18.

192 Ibid. See also publications on climate justice movements by Transnational Institute (Brand et al, supra note 89) and reflections in Turbulence 5 "And now for something completely different", online: <http://turbulence.org.uk/turbulence$5 />$.

193 See also Patrick Bond's discussion of the Durban COP where he explores in detail both the failures of the COP but also the movement strategy to successfully delegitimize it or connect questions of climate justice with grounded, local struggles. Patrick Bond, "Durban's conference of polluters" (2012) 12:1/2 Ephemera: Theory and Politics in Organisation 42.

194 Larry Lohman, "Beyond Patzers and Clients - Strategic Reflection on Climate Change and the "Green Economy", in Niclas Hällström, ed, What Next Volume Next III: Climate, Development and Equity (Dag Hammarskjöld Foundation and What Next Forum, 2012) at 295. 
that critiques of the UNFCCC and controversies surrounding "false solutions" may have "succeeded beautifully in distracting public and official attention from the underlying issues", ${ }^{195}$ namely continued fossil fuel extraction, and done little to build the forms of commonality necessary to combat this.

A jurisdictional approach helps highlight the way in which commonality has been organized within the regime, but also what other possibilities for the organization of commonality could be envisioned. A different way of patterning commonality, distinct from the above discussion, of both the political and economic forms of international ordering, would be to understand climate mitigation in terms of situated and contextual transitions towards decarbonization that are globally coordinated while focused on specific "place-based" struggles. Moreover, this structuring of commonality around transnationallyshared rejection of a specific developmental model and the logic of extractivism, is not utopian but is being actualized through various struggles at the more local scale.

In theorizing social movements I draw on the history of "militant-research", which the Argentinean collective, Colectivo Situacions, describes as a "form of intervention and knowledge production that 'reads' struggles from within". ${ }^{196}$ Geographer Bertie Russell, reflecting on his own experiences as a researcher/participant in the 2007 Camp for Climate Action at London's Heathrow Airport, envisions "militant research" as an orientation that rejects the university as a referent, positioning its objective instead as producing research that "contribute(s) to processes of critical reflection and transformation of our movements" or "making movements move" ${ }^{197}$ I suggest that developing a framework through which to think of the practices of social movements not just in political terms, but also in legal terms, or in terms of the forms of "lawful relations" they establish, is one contribution critical legal scholars can make.

Pearse and Böhm flag "cooperative decarbonisation" as an emerging international framework for international action that is focused on particular industries or commodities, ${ }^{198}$ citing Christoff and Eckersley's discussion of a "coal non-proliferation treaty". ${ }^{199}$ Arun Martin has explored the possibility of a "coal-export safeguard regime" as an alternative regulatory strategy to "manage the end-use transboundary pollution risks embodied in coal exports". ${ }^{200}$ While the UNFCCC focuses on current and future mitigation, this patterning of commonality includes responsibility for historic, present and future harms. It is a commonality articulated against fossil fuels in particular, and it does not seek to posit that the concern for the climate is universally shared. In her recent book, Naomi Klein discusses a

195 Ibid at 319.

196 Cited in Nate Holdren \& Sebastian Touza, "Translators' Preface" in Colectivo Situaciones, 19 \& 20: Notes for a New Social Protagonism, translated by Nate Holdren \& Sebastián Touza (New York: Minor Compositions, 2002) at 3. See also Colectivo Situaciones, "On the researcher-militant" (2003) translated by Sebastian Touza, online:

$<$ http://eipcp.net/transversal/0406/colectivosituaciones/en>.

197 Bertie Russell, "Beyond activism/academic:militant research and the radical climate and climate justice movement(s)" (2014) Area . In relation to the role of academic/activists in the climate movement see also Kevin Mason, "Academics and Social Movements: Knowing Our Place, Making Our Space”(2013) 12:1 ACME: An International E-Journal for Critical Geographies 23.

198 Pearse \& Böhn, supra note 49 at 9.

199 Peter Christoff \& Robyn Eckersley, “A Coal Non-Proliforation Treaty?” Paper presented to the Beyond Coal workshop, cited in Pearse \& Böhm, supra note 49.

200 Aran Martin, "Commodity exports and transboundary atmospheric impacts: regulating coal in an era of climate change" (2014) 23:4 Env Pol 590. 
transnational movement she calls "blockadia": the "increasingly interconnected pockets of resistance" against fossil fuels that are "blocking pipelines, opposing new extraction projects, and quite willingly putting bodies on the line". ${ }^{201}$ For her, these "place-based stands" that are "stopping climate crimes in progress" $" 202$ are creating a "transnational space, roving space, where regular people are stepping in where our leaders are failing" 203 and providing a "moral antidote" to political inaction. ${ }^{204}$

At times, these actions are explicitly "internationalized". For example, in October 2014, a group of activists from 12 Pacific countries, calling themselves the Pacific Climate Warriors, using traditional canoes, blockaded the Newcastle Coal Export Terminal in Australia, the largest coal port in the world, stopping all ships for a day. Their slogan was "we're not drowning, we're fighting". ${ }^{205}$ In July 2015, Greenpeace activists swung from the St. Johns Bridge in Portland, Oregon for over 24 hours, creating a human blockade to prevent Shell's icebreaking ship, Fennica, from leaving for the Arctic to assist with exploratory drilling. ${ }^{206}$ They carried enough food for a week as they dangled on ropes from the bridge and unfurled banners fluttering red and yellow against the Pacific, supported by "kayaktivists" in the water below. Klein argues that this "resistance to high-risk extreme extraction is building a global, grassroots, and broad-based network the likes of which the environmental movement has rarely seen". 207 She hesitates to call it an "environmental" movement because, she argues, the stakes are higher, interpreting the movement as "primarily driven by a desire for a deeper form of democracy, one that provides communities with real control over those resources that are most critical to collective survival the health of the water, air, and soil". ${ }^{208}$

Klein has rightly been criticized by Jodi Dean for the simplification she makes in which "local environmentalism" is always counterpoised to "global extractivism", which fails to engage with the complex relations in which "locally-based" groups may be just as likely to support environmentally-

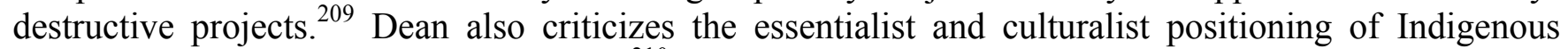
identity in the slot of the "noble savage", ${ }^{210}$ which embraces a "cannibalistic Western logic that readily constructs other cultural possibilities as resources for Western needs and actions." ${ }^{11}$ Rather than

201 Naomi Klein, This Changes Everything: Capitalism vs. the Climate (New York: Simon \& Schuster, 2014) [Klein, This Changes Everything].

202 Ibid at 295.

203 "Naomi Klein on the People's Climate March and the Global Grassroots Movement Fighting Fossil Fuels", Democracy Now, (18 September 2014), online: <http://www.democracynow.org/2014/9/18/naomi_klein_on_the_peoples_climate>.

204 Klein, This Changes Everything, supra note 201 at 295.

205 "The coal port is the largest in the world and there are plans for it to expand and we want to bring the message that the expansion is definitely going to have an effect on the islands, not just in the Marshalls but all over the Pacific," said Milan Loeak, online: Australian Broadcasting Corporation <http://www.abc.net.au/news/2014-10-13/pacific-climatewarriors-to-protest-newcastle-coal-port/5809392>.

206 Christine Hauser, "Greenpeace Activists Dangle from Oregon Bridge for 2nd Day to Protest Arctic Drilling", New York Times (30 July 2015) online: http://www.nytimes.com/2015/07/31/us/greenpeace-activists-dangle-from-oregon-bridgefor-2nd-day-to-protest-arctic-drilling.html?_r=1.

207 Klein, This Changes Everything, supra note 201 at 295.

208 Ibid.

209 Jodi Dean, "This Changes Some Things" I Cite, (17 March 2015), online: <http://jdeanicite.typepad.com/i_cite/2015/03/this-changes-some-things.html $>$.

210 Ibid.

211 Harroway cited in Larry Lohmann, “Green Orientalism” (Dorset, UK: The Corner House, 1993). 
assuming particular positions or identities, or assuming identities equate to specific forms of political action, a focus on the way a commonality is being actualized directs attention to the messy, contested processes of alliance-building or how identifications are themselves constituted in and by struggle. As Gigi Roggero insists, "political composition [is] a process". ${ }^{212}$ The construction of a commonality as a genuine meeting point is, like any construction of mutual solidarities, not a "smooth process" but fraught and transversed with antagonisms. ${ }^{213}$ A global "common concern" therefore cannot simply be posited, but more attention needs to be given to the hard work involved in building commonalities, at times through grounded material practices of solidarity.

Analytical attention to this requires more focus on the plurality of laws and jurisdictional forms. For example, on 23-25 January 2013, representatives from Indigenous Nations, tribes, and governments met on Ihanktonwan homelands for a "Gathering to Protect the Sacred", the conclusion of which was the signing of an "International Treaty to Protect the Sacred from Tar Sands Projects". 214 "We affirm that our laws define our solemn duty and responsibility to our ancestors, to ourselves, and to future generations, to protect the lands and waters of our homelands." 215 This project is interesting for the performativity it entails; it references historical treaties between Indigenous collectivities, but also references the grammar of international legal treaties and the ceremony of treaty-making processes from which international law excludes Indigenous groups. Anne Orford has drawn attention to the lack of consideration by non-Indigenous lawyers of "indigenous law as a source of law governing relations between nations - that is, as a source of international law" because international law's recognition of law and its sources reflects the law of the powerful, the traditions of the occupiers and that which derives from the nation state. ${ }^{216}$ She highlights the insufficiency of this approach, insisting instead that "international law must itself be understood as plural with the legal spaces of the South if justice is to be possible". 217

212 Gigi Roggero, "Five Theses on the Common" (2010) 22:3 Rethinking Marxism: A Journal of Economics, Culture \& Society 357

213 Cumbers cited in Mason, supra note 197 at 38.

214 "International Treaty to Protect the Sacred from Tar Sands Signing Ceremony", IC Magazine, 2 February 2013, online: $<$ https://intercontinentalcry.org/international-treaty-to-protect-the-sacred-from-tar-sands-signing-ceremony/>.

215 Ibid. See also that in September 2014, First Nations from southern British Columbia and Vancouver Island, Canada and Washington State, United States, signed an International Treaty to Protect the Sacredness of the Salish Sea, which declared the Kinder Morgan Trans Mountain Expansion Project 'illegal' under Salish Coast Law and explicitly recognized the threat posed by climate change. Article I provides:

"We are the Indigenous Peoples of the Salish Sea. We are distinct peoples, each with our own territories, languages \& cultures, but bound together by interlocking ties of kinship and our deep connection to the Salish Sea and the waters that flow into it. The Salish Sea has been our home, the feast bowl of our sustenance, and the place through which we connect with all our ancestral and living relations. It is the source of our stories, traditions, and ancestral privileges and prerogatives. Our ancestral laws placed upon us the sacred responsibility to protect the Salish Sea and the tributaries that feed it. The wellbeing of our intellect, emotions, spirit and bodies depend on the wellbeing of the Salish Sea."

Tsleil-Waututh Nation Sacred Trust Initiative, "International Treaty to Protect the Salish Sea", online: $<$ http://www.protectthesacred.org/intl_treaty_to_protect_the_sacredness_of_the_salish_sea $>$.

216 Anne Orford, "Ritual, Mediation and the International Laws of the South" (2007) 16 Griffiths L Rev 353 at 353.

217 Ibid at 372. 
From a perspective akin to jurisdictional patterning or ordering of the international, such movements described can be understood in legal terms as experiments towards a different patterning of commonality, where a shared "common concern" does not authorize an expanded international jurisdiction. Rather, the shared concern represents a potential "meeting place" of situated and contextual conjunctures, themselves invariably a product of local and global factors. This is a patterning based upon an expression of a shared "no" to the degradation of communities and the land, but potentially also ingrained in them is a resounding "yes", in that such practices of disruption can also be the "affirmative enactment of another modality of being, a different way of relating to and with the world" and, at times, underpinned by and authorized by different laws. ${ }^{218}$

\section{CONCLUSION}

This article has explored Third World, civil society and climate justice movements' critiques of dominant, market-orientated approaches to addressing the climate crisis under the UNFCCC. It first outlined the critiques of carbon markets made by activists and scholars and documents a long history of protest against approaches adopted by the UNFCCC. It then discussed approaches of Third World states and scholars to climate change, arguing that although the principle differentiation in international climate law continues to be critical, much more attention needs to be paid to the way the principle of CBDR is being interpreted and what it authorizes. Moreover, I suggested this principle assumed a specific organization of "common responsibilities" that in the increasingly "bottom-up" regime is no longer present. The next section of the article drew attention to the different ways in which a "common concern" about the climate crisis can be articulated. It adopted a jurisdictional approach in order to pay attention to the plurality of jurisdictional forms that the organization of "commonality" can take. This section paid attention to how the UNFCCC was authorized by the invocation of a "common concern" and how this concept of "common concern" was articulated in practice over time as the regime developed. This analysis showed that, although the operations of carbon markets continue to rely on an "economic commonality" to justify offsets in the interests of economic efficiency, the "political" organizations of the regime increasingly became more decentralized. This analysis highlighted the very different organization of the "economic" and the "political" in the international climate regime. The final substantive section of the article explored a different way of organizing a "common concern", drawing on the practices of a global movement against fossil fuel extraction and in defence of land. It suggested that such a patterning of a global "common concern" that allowed for a plurality of perspectives and laws presents perhaps the best hope for decolonial forms of climate justice. At this critical conjuncture, this article has suggested that the ways in which global commonality is organized and patterned are critical. The concept of "common concern" is neither innately colonial or decolonial,

218 Glen Sean Coulthard, Red Skin, White Masks: Rejecting the Colonial Politics of Recongition (Minneapolis: University of Minnesota Press, 2014) at 169. This argument draws heavily on Coulthard's theorizations of the use of blockades as a decolonization strategy in the context of Canadian settler-colonialism. The blockades he is describing are much broader than, but at times do overlap with, blockades against extractivism. For him, such blockades as well as being reactive are also affirmative in that they are an enactment of Indigenous law. 
however the different ways in which commonality is jurisdictionally organized have very different implications. 